\title{
Phytogeography of the vascular páramo flora of Ramal de Guaramacal (Andes, Venezuela) and its ties to other páramo floras
}

\author{
by \\ Nidia L. Cuello ${ }^{1}$, Antoine M. Cleef ${ }^{2} \&$ Gerardo Aymard $^{3}$ \\ ${ }^{1,3}$ Universidad Nacional Experimental de los Llanos Ezequiel Zamora (UNELLEZ-Guanare), Programa de Ciencias del Agro y del Mar, \\ Herbario Universitario (PORT), Mesa de Cavacas, Estado Portuguesa 3323, Venezuela. ncuello@cantv.net; gaymard@cantv.net \\ ${ }^{2}$ Institute for Biodiversity and Ecosystem Dynamics (IBED), University of Amsterdam, Science Park 904, \\ 1098 HX Amsterdam, The Netherlands. cleef@uva.nl.
}

\begin{abstract}
Cuello, N.L., Cleef, A.M. \& Aymard, G. 2010. Phytogeography of the vascular páramo flora of Ramal de Guaramacal (Andes, Venezuela) and its ties to other páramo floras. Anales Jard. Bot. Madrid 67(2): 177-193.

Ramal de Guaramacal is an outlier and lower elevation mountain range located at the northeastern end of the Venezuelan Andes. Phytogeographical patterns and affinities of the low altitude and wet vascular páramo flora of Ramal de Guaramacal, have been studied with emphasis in to the analysis of the floristic connections of the Guaramacal páramo flora with the neighboring dry páramos of the Sierra Nevada de Mérida and other páramo floras of the northern Andes and Central America. A total of 252 vascular plant taxa belonging to 150 genera and 69 families were recorded from the study area. The most species rich families are Asteraceae, Poaceae, Ericaceae and Orchidaceae, followed by the ferns families Grammitidaceae and Lycopodiacae. The most diverse genera are the ferns Elaphoglossum, Huperzia and Hymenophyllum. The analysis of generic phytogeographical composition of páramo flora showed that $52.8 \%$ of the genera are Tropical. The Temperate component is represented by $33.3 \%$ of the genera and the Cosmopolitan component is represented by $13.9 \%$ of the genera. The Neotropical montane element (38.9\%) is high in Guaramacal páramo, the Páramo endemic element (1.9\%) and the Andean alpine element $(0.9 \%)$ and represented by only one genus (Lachemilla) are low compared to other páramo areas. The vascular flora of Páramo de Guaramacal is largely composed of (1) a group of Neotropical widespread distributed species (32\%), (2) a group of Andean distributed species (49\%), part of them confined to the Northern Andes and part widespread in the Andes from Colombia to Bolivia, and (3) a group of Venezuelan endemics (19\%). From an eight páramo flora comparative dataset, the closest relationships among páramos is observed between the generic páramo floras of the Colombian Cordillera Oriental of Sumapáz and Sierra Nevada del Cocuy, which are both close-
\end{abstract}

\section{Resumen}

Cuello, N.L., Cleef, A.M. \& Aymard, G. 2010. Fitogeografía de la flora vascular del páramo de Ramal de Guaramacal (Andes, Venezuela) y sus conexiones con otras floras de páramo. Anales Jard. Bot. Madrid 67(2): 177-193 (en inglés).

El Ramal de Guaramacal es una pequeña ramificación montañosa ubicada al extremo nororiental de los Andes venezolanos. Se estudiaron los patrones fitogeográficos y afinidades de la flora vascular de páramo húmedo y de baja altitud del Ramal de Guaramacal, con énfasis en el análisis de sus conexiones florísticas con páramos secos cercanos de la Sierra Nevada de Mérida y otras floras de páramo de los Andes del Norte y Centroamérica. En el área de estudio se han registrado un total de 252 táxones de plantas vasculares pertenecientes a 150 géneros y 69 familias. Las familias más ricas en especies son Asteraceae, Poaceae, Ericaceae y Orchidaceae, seguidas por las familias de helechos Grammitidaceae y Lycopodiacae. Los géneros más diversos son los helechos Elaphoglossum, Huperzia e Hymenophyllum. El análisis de composición fitogeográfica a nivel genérico de la flora de páramo mostró que el 52,8\% de los géneros es Tropical. El componente Templado está representado por el 33,3\% de los géneros; y el componente Cosmopolita, por el 13,9\%. El elemento Montano Neotropical (38.9\%) es alto en el páramo de Guaramacal; los elementos Endémico de Páramo (1,9\%) y Alpino Andino (0,9\%), representado sólo por un género (LachemiIla), son bajos en comparación con otras áreas de páramo. La flora vascular de Páramo de Guaramacal está integrada en gran medida por: 1) un grupo de especies de distribución amplia neotropical $(32 \%), 2)$ un grupo de especies de distribución Andina (49\%) -parte de ellas se limita a los Andes del Norte y parte se generaliza en los Andes desde Colombia hasta Bolivia- y 3) un grupo de especies endémicas de Venezuela (19\%). De la comparación del conjunto de datos de flora de ocho páramos, las relaciones más cercanas entre éstos se observan entre las floras genéricas de los páramos de la Cordillera Oriental colombiana, Sumapáz y Sierra Nevada del Cocuy, los cuales están estrecha- 
ly related to that of the Sierra Nevada de Mérida in Venezuela. The generic páramo flora of Ramal de Guaramacal shows the closest relationship to southern Ecuador páramo flora of Podocarpus Biosphere Reserve. According to Detrended Correspondance Analysis and Principal Component Analysis ordination results, most of the variations in páramo floras may represent a response to differences in ambient humidity.

Key words: páramo flora, phytogeography, Andes, Venezuela, Talamancas.

\section{Introduction}

Páramo is the open equatorial alpine vegetation located above the upper forest line (UFL) and below the permanent snow line from the northern Andes to Panamá and Costa Rica. However, páramo is also considered to be extended to the Amazon slopes of Bolivia (García \& Beck, 2006; Rangel, 2006). Páramo flora is considered the high-mountain flora most rich in species of the world (Smith \& Cleef, 1988). Phytogeographical studies at the generic level have shown that páramo flora has evolved mainly by immigration of cool-adapted plants from temperate regions (temperate elements) and, in relatively lower proportion, by adaptation of lower-elevation plants (tropical elements) to high-altitude environments and by speciation through repeated isolation in situ (Van der Hammen \& Cleef, 1986; Smith \& Cleef, 1988; Cleef \& Chaverri, 1992; Ramsay, 1992; Ricardi \& al., 1997; Sklenáŕ \& Balslev, 2007).

Páramo areas in Venezuela exhibit great environmental variability in climate at regional and local scales. Through the about $400 \mathrm{~km}$ southwest to northeast extension of the main Venezuelan Andean mountain chain, the Cordillera de Mérida, there is a wide range of páramo hydrological conditions, from dry páramos with $650 \mathrm{~mm} /$ year in a single rainy season, to permanently humid páramos with over $3000 \mathrm{~mm}$ distributed throughout the year (Monasterio \& Reyes, 1980). The latter conditions characterize the páramo areas of Ramal de Guaramacal, an outlier and comparatively low elevation $(3130 \mathrm{~m})$ range located at the northeastern end of the Venezuelan Andes (Fig. 1).

North Andean páramo vegetation has been divided into several altitudinal zones (for a complete review we refer to Luteyn 1999). The Cuatrecasas (1934, 1958) altitudinal classification of superpáramo, páramo and subpáramo has since been widely adopted (Cleef, 1981; Acosta-Solís, 1984; Ramsay, 1992; Jørgensen \& Ulloa, 1994; Luteyn, 1999; Hooghiemstra \& al., 2006; Rangel-Ch., 2000a). For Venezuelan páramos, Monasterio (1980) recognises two altitudinal zones called 'pisos altitudinales': a High Andean mente relacionados con la Sierra Nevada de Mérida en Venezuela. La flora genérica de páramo del Ramal de Guaramacal muestra la relación más cercana con la flora de páramo de la Reserva de Biosfera Podocarpus al sur del Ecuador. Según los resultados de ordenación DCA y PCA, la mayoría de las variaciones en las floras de los páramos analizados pueden representar una respuesta a diferencias de humedad ambiental.

Palabras clave: flora de páramo, fitogeografía, Andes, Venezuela, Talamancas.

zone or 'Piso Altiandino' (4000-4800 m) and the Upper Andean zone or 'Piso Andino Superior' (2800$4000 \mathrm{~m}$ ).

Studies of phytogeography of the Venezuelan páramo flora started with a first approach of the worldwide distribution of Venezuelan páramo flora presented by Faría (1978) after the publication of the 'Flora de los Páramos de Venezuela' by Vareschi (1970). This very first flora of the páramos was not complete, but anyway representative.

Local floristic listings and phytogeographical analyses that include páramo areas such as those from Táchira and Trujillo states have appeared (Bono, 1996; Ortega \& al., 1987; Rivero \& Ortega, 1989; Aymard, 1999; Dorr \& al., 2000). Bono (1996) also included a phytogeographical breakdown into geographic flora elements of the páramo flora of Táchira State, Venezuela.

More recent phytogeographical analyses of the Venezuelan páramo flora have been published by Ricardi \& al. $(1997,2000)$. The first study deals with the phytogeography of the Mérida superpáramo; the second study highlights the Sierra Nevada de Mérida as a new phytogeographical subprovince of the northern Andes. Briceño \& Morillo $(2002,2006)$ recently published a list of the flowering species of the Venezuelan Andean páramos, first the dicots, later followed by the monocots.

The aim of this study is to analyse the phytogeographical affinities of the low altitude and wet páramo of Ramal de Guaramacal in order to contribute to a better understanding of the distribution, origin, and diversity of its flora. A detailed analysis of phytogeographic composition of Ramal de Guaramacal páramo flora at a genus level is justified given the importance of this low, wet and relative isolated mountain range from the main Cordillera, which also shows a distinctive flora and vegetation composition (Cuello \& Cleef, 2009b). Particular emphasis is given to the analysis of the floristic connections of the Guaramacal páramo flora with the neighboring dry páramos of the Sierra Nevada de Mérida and other páramo floras of the northern Andes and Central America. 
One of our main objectives was to determine whether the phytogeographical analysis and patterns of the páramo flora of Ramal de Guaramacal are determined by temperature (a function of altitude) as has been established in previous studies (e.g. Cleef, 1979; Mérida Andes, Ricardi \& al., 1997, 2000) or more by the overall humidity, which characterizes the Guaramacal bamboo páramo. We have some indications that ambient humidity may play a role, e.g. in the case of the bamboo páramo of Tatamá (Cleef, 2005), the páramos of Podocarpus National Park (PNP) in southern Ecuador (Lozano \& al., 2009) and also in the Talamancas of Costa Rica (Cleef \& Chaverri, 1992).

\section{Materials and methods}

\section{Study area}

Ramal de Guaramacal is located south of the town of Boconó, Trujillo state, approximately $120 \mathrm{~km}$ Northeast of Mérida, in the centre of the Sierra Nevada de Mérida (Fig. 1). Páramo areas of the summit of Ramal de Guaramacal are found between 2800-3100 $\mathrm{m}$, in the surroundings and between of 'Las Antenas' area (9 $\left.14^{\prime} 1.02 " \mathrm{~N} ; 70^{\circ} 11^{\prime} 6.47^{\prime \prime} \mathrm{W}\right)$ and Páramo El Pumar (9¹2'45.6” N; 70¹2'5.55” W), 2.5 km Southwest of 'Las Antenas'.

The climate is very humid. According the first climatic records of the Davis Pro 2 climate station installed near the summit of Guaramacal $(3100 \mathrm{~m})$ by the first author beginning in December 2006, there are over 290 days/year of rain. Maximum precipitation occurs during April-July. Yearly precipitation is high, reaching over $3200 \mathrm{~mm} /$ year and relative humidity attains $100 \%$ most of the year. Temperatures remain low throughout the year with a diurnal temperature variation from $4-6^{\circ} \mathrm{C}$ to $14-16^{\circ} \mathrm{C}$; mean minimum temperature of $5.3^{\circ} \mathrm{C}$ and mean maximum of $12.3{ }^{\circ} \mathrm{C}$; the lowest temperatures recorded being between $-0.1-1.3^{\circ} \mathrm{C}$ in the month of January; the highest between $17.8-18.3^{\circ} \mathrm{C}$ in the month of March, with mean yearly temperature of $8.1-8.6^{\circ} \mathrm{C}$ for the period from December 2006 - July 2009. Dominant wind directions are of ESE, SE and WNW, with a registered average speed of 3.9-5.8 km/h. Maximum wind speed registered has been of $77.2 \mathrm{~km} / \mathrm{h}, \mathrm{SE}$ in the month of July 2008.

The vegetation of the Páramo of Guaramacal is characterized by a mosaic of subpáramo formations (shrub páramo, bunchgrass páramo, most common bamboo páramo), intermingled with patches of dwarf forests (Subalpine Rain Forest or SARF sensu Grubb 1977), distributed between 2800 and $3130 \mathrm{~m}$ (Cuello \& Cleef, 2009a, b). For detailed information on forest

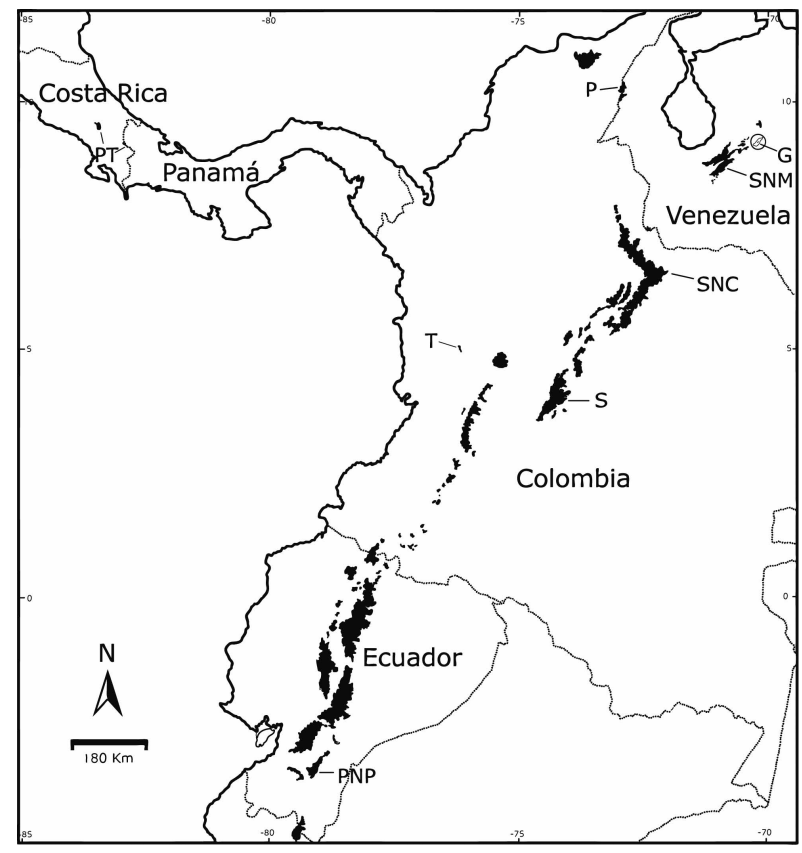

Fig. 1. The location of Guaramacal páramo study site $(\mathbf{G})$ and the other páramo areas in northern South America and Central America which floristic comparison are made: Sierra Nevada de Mérida (SNM) in Venezuela, Talamancas páramos (PT) in Costa Rica-Panamá; Sierra Nevada del Cocuy (SNC), Serranía de Perijá (P), Tatamá massif (T) and Sumapaz páramo (S) in Colombia; Podocarpus National Park (PNP) in southern Ecuador.

and páramo vegetation of Guaramacal and other aspects of the study area we refer to Cuello \& Cleef (2009a, b, c) and Cuello (1999).

The study and full inventory of the flora of the whole Ramal de Guaramacal range is still ongoing. Preliminary accounts of the vascular flora were first presented by Ortega \& al. (1987) and later by Dorr \& al. (2000). After that, several new records for the flora as well as new species to science have been documented for Guaramacal (Taylor, 2002; Stergios \& Dorr, 2003; Stančík, 2004; Niño \& al., 2005; Cuello \& Aymard, 2008). A species inventory from páramo areas, including, páramo and subpáramo-connected dwarf forest vegetation islands is presented in this study (Appendix 1).

\section{Methods}

Páramo data were collected from phytosociological studies (Cuello \& Cleef, 2009b, c) and 585 numbers of general plant collections made by the first author from páramo areas of Ramal de Guaramacal. Additional information was obtained from herbarium collections and database of Herbario Universitario PORT, UNELLEZ in Guanare. The total inventory included 255 vascular plant taxa belonging to 153 
genera and 69 families that are listed in Appendix 1. Three exotic weedy taxa (Polypogon elongatus, Rumex acetosella and Sonchus oleraceus) present in disturbed areas, are listed in the Appendix 1, but excluded for the analyses.

For each vascular genus listed the present geographical distribution has been determined on basis of Mabberley (2008); occasionally also recent phylogenetic studies (e.g. Chacón \& al., 2006: Oreobolus; von Hagen \& Kadereit, 2003: Halenia; Meudt \& Simpson, 2007: Ourisia, etc.). Species distribution was also determined by literature and by the W3Tropicos database. Plant genera have been grouped into different phytogeographical elements belonging to three mayor components according to Cleef (1979, 1981, 2005) and Cleef \& Chaverri (1992).

1) The Tropical component is made up of four flora elements: (a) Wide tropical (WTR) taxa; (b) Andean alpine (NT-AA) taxa; (c) Páramo endemics (P); (d) Neotropical montane elements (NT-M). Thus, the former 'Other Neotropical elements' (Cleef, 1979), viz. 'Neotropical-montane element' (Cleef \& Chaverri, 1992) is subdivided into the Andean alpine element (NT-AA) and Neotropical montane element (NT-M) following Simpson \& Todzia (1990) and Sklenář \& Balslev (2007).

2) Temperate component contains three flora elements: (a) Widely distributed temperate (WTE) taxa; (b) Holarctic (HO) groups; (c) Austral-Antarctic (AA) taxa.

3) Cosmopolitan component consists of only the Cosmopolitan taxa (CO).
For a biogeographical analysis into species level, overall species distribution was grouped into ten different geographic elements, adapting from previous phytogeographical studies in the Andean region such as those used by Kelly \& al. (1994) and Schneider (2001). From the total 252 taxa recorded for the Guaramacal summit area, for the specific biogeographical analysis we used only 229 species with a defined distribution (those which were determined to species and/or infraespecific level), including all open páramo and dwarf forest islands (of Subalpine Rain Forest or SARF sensu Grubb 1977) vegetation species.

Floristic relationships of Guaramacal páramo generic flora to other páramo floras of the northern Andes and Central America were assessed using ordination (Detrended Correspondance Analysis - DCA, Principal Component Analysis - PCA) and classification (Cluster analysis) methods for seven additional available different páramo flora datasets. Floristic lists from each páramo site were obtained from literature or unpublished data from authors (see Table 1). The accounts on the different páramo floras were carefully screened by the authors for taxonomic update and true forest taxa were deleted. Two dataset were considered for these analyses, A) one which included the Guaramacal list of total genera of 150 from páramo \& SARF combined, and B) the other that includes Guaramacal list of 108 genera from open páramo only. For these analyses, both data matrices A (404 genera $\times 8$ sites $)$ and $\mathrm{B}$ ( 347 genera $\times 8$ sites $)$ of presence/absence of genera in the eight páramo floras were analyzed using program PC-Ord 4 (McCune \&

Table 1. Reference information for the eight páramo flora dataset used for comparative multivariate analysis.

\begin{tabular}{|c|c|c|c|c|c|}
\hline Páramo & $\begin{array}{l}\text { Max. Elev. } \\
\quad(\mathrm{m})\end{array}$ & $\begin{array}{l}\text { Aprox. Prec. } \\
\text { (mm/year) }\end{array}$ & $\begin{array}{l}\text { Area } \\
\text { (ha) }\end{array}$ & $\begin{array}{l}\text { Number of genera } \\
\text { considered }\end{array}$ & $\begin{array}{l}\text { Source of } \\
\text { floristic data }\end{array}$ \\
\hline Sierra Nevada del Cocuy, Colombia & 5330 & 1300-ca. 3000 & 112418 & 213 & Cleef, unpubl. data \\
\hline Sierra Nevada de Mérida, Venezuela & 4980 & $813-1811$ & 69100 & 149 & $\begin{array}{l}\text { Ricardi \& al., 1997; } \\
\text { Berg \& Suchi, } 2001\end{array}$ \\
\hline Sumapaz, Cordillera Oriental, Colombia & 4250 & $\sim 1200-3000$ & 102945 & 211 & $\begin{array}{c}\text { Cleef, 1979; Franco \& } \\
\text { Betancur, 1999; } \\
\text { Pedraza-Peñaloza \& al., } \\
\text { 2004; Rangel-Ch., 2000b }\end{array}$ \\
\hline $\begin{array}{l}\text { Tatamá massif, Cordillera Occidental, } \\
\text { Colombia }\end{array}$ & 4100 & $>3000$ & 5000 & 114 & $\begin{array}{l}\text { Cleef \& al., 2005; } \\
\quad \text { Cleef, } 2005\end{array}$ \\
\hline Serranía de Perijá, Colombia & 4100 & $\sim 2000$ & 4560 & 137 & Rivera-Díaz, 2007 \\
\hline Talamancas, Costa Rica/Panamá & 3850 & $2000-4000$ & 15205 & 177 & $\begin{array}{c}\text { Barrington, 2005; } \\
\text { Vargas \& Sánchez, } 2005\end{array}$ \\
\hline $\begin{array}{l}\text { South Ecuador: Podocarpus } \\
\text { National Park (PNP) }\end{array}$ & 3695 & $\sim 5000 \mathrm{~mm}$ & 14169 & 201 & $\begin{array}{l}\text { Lozano \& al., 2009; } \\
\text { Bussmann, 2002; } \\
\text { Keating, } 1999\end{array}$ \\
\hline Guaramacal, Venezuela & 3130 & $>3200 \mathrm{~mm}$ & $\sim 400$ & $150 / 109$ & This study \\
\hline
\end{tabular}


Mefford, 1999). Cluster analyses of shared genera used Sørensen (Bray-Curtis) as distance measure method and Group Average as group linkage method.

\section{Results}

\section{Flora characteristics}

To date, the vascular flora of summit areas of Ramal de Guaramacal is composed of a total of 252 taxa; 17 families, 28 genera, and 68 species of ferns, and 52 families, 122 genera and 184 species of angiosperms. In general, the most species rich families are Asteraceae, Poaceae, Ericaceae and Orchidaceae, followed by the ferns families Grammitidaceae and Lycopodiacae.

The most diverse genera are the ferns Elaphoglossum, Huperzia and Hymenopbyllum. Of the 252 taxa considered, only 169 species belonging to 108 genera have been registered for proper subpáramo-páramo vegetation, excluding the SARF vegetation (Table 2).

\section{Geographical composition of genera}

The composition of genera of phytogeographic elements in páramo areas of Ramal de Guaramacal is presented in Table 3. A total of 150 genera is contained in Table 3, including 41 genera of woody, herbaceous and epiphytic plant species found inside the forest islands (of SARF vegetation) surrounded by páramo vegetation, and 27 genera present in azonal páramo vegetation. Proportions of phytogeographic elements and components of the studied data set are shown in Fig. 2, represented separately for: (a) all genera inclunding SARF vegetation, (b) all open páramo genera, and (c) for the genera present in azonal communities.

\section{Tropical component}

On the basis of 150 vascular plant genera more than half $61.3 \%$ (92 genera) are tropical. Neotropical montane element genera are those that range from montane forest into the supraforest zone. This element is represented by 64 genera $(42.7 \%)$. Twenty two of them (including 10 herbaceous genera) correspond to SARF vegetation (Table 3 ). When considering only the genera recorded from páramo vegetation, the Neotropical montane element is represented by forty two genera $(38.9 \%)$, four of them are found in azonal páramo (Fig. 2c).

Wide tropical element genera are widely distributed in the tropics, including those exclusively African-American and Asian-American. This element is represented by 24 genera (16\%). Ten of them (including five herbaceous genera) were found in SARF islands (Table 3). When considering only páramo vegetation genera, the wide tropical element accounts for twelve genera $(11.1 \%)$ and only one of them (Xyris) is found in azonal páramo.

Páramo endemic element genera are those confined to páramo (and sometimes also in the downslope Andean forests) and represented in the study area by 3 genera $(2 \%)$, two of them small trees: Liba-

Table 2. Most diverse families and genera from the vascular flora of summit areas (including SARF and excluding exotic weeds) of Ramal de Guaramacal, Andes, Venezuela. For only proper páramo flora numbers of taxa are indicated in parenthesis.

\begin{tabular}{|l|c|c|c|c|}
\hline FAMILY & Number Genus & Number spp. & Genus & Number spp. \\
\hline Asteraceae & $14(10)$ & $24(17)$ & Elaphoglossum & $11(5)$ \\
Poaceae & 10 & $21(20)$ & Huperzia & $8(6)$ \\
Ericaceae & $10(8)$ & $15(13)$ & Hymenophyllum & $7(2)$ \\
Orchidaceae & $9(4)$ & $14(7)$ & Chusquea & $7(6)$ \\
Grammitidaceae & $6(3)$ & $13(6)$ & Rhynchospora & 6 \\
Lycopodiaceae & 3 & $14(10)$ & Gaultheria & 5 \\
Cyperaceae & 4 & 10 & Hypericum & 4 \\
Dryopteridaceae & $2(1)$ & $12(5)$ & Blechnum & $4(2)$ \\
Rubiaceae & $6(5)$ & $7(6)$ & Melpomene & 4 \\
Hymenophyllaceae & 1 & $7(2)$ & Miconia & $4(1)$ \\
Melastomataceae & 3 & $6(3)$ & Ruilopezia & $4(2)$ \\
Bromeliaceae & 4 & 5 & 4 \\
Myrsinaceae & $3(2)$ & $5(3)$ & Weinmannia & $4(0)$ \\
Clusiaceae & 1 & 4 & & \\
Rosaceae & 3 & 4 & & \\
Blechnaceae & 1 & $4(2)$ & & \\
Cunoniaceae & $1(0)$ & $4(0)$ & & species \\
\hline Totals 69(53) families & $150(108)$ & & & \\
\hline
\end{tabular}


nothamnus at the UFL and Paragynoxys, a species from SARF. Most spectacular are the 4 species of Ruilopezia (Espeletiinae), endemic for Venezuela. Only one Páramo endemic genus (Ruilopezia) is found in azonal páramo.

The Andean alpine element is represented by only one herbaceous genus $(0.7 \%)$ : Lachemilla, which is found mainly in azonal páramo.

\section{Temperate component}

Forty two genera are of temperate distribution $(28 \%)$, including six genera from SARF. When considering only páramo vegetation genera, the temperate component is represented by 36 genera or $33.3 \%$. These include 31 herbaceous genera, 16 of them counted from azonal páramo.
Widespread temperate element genera are distributed in temperate and cool regions from both hemispheres. This element is represented in the study area by twenty one genera (14\%). The genus Stellaria was recorded from borders of SARF vegetation. When excluding this genus, the wide temperate element is represented by $18.5 \%$ for twenty páramo genera, eight of them counted from azonal páramo.

Austral-Antarctic element genera have southern temperate distribution. This element is represented by fifteen genera (10\%). Among them, three genera were registered from SARF (Table 3). Twelve AustralAntarctic element genera (including 8 herbaceous) of only páramo vegetation account for $11.1 \%$. Eight genera are counted from azonal páramo.

Holarctic element genera have northern temperate

Table 3. Composition of genera of phytogeographic elements in páramo areas of Ramal de Guaramacal in the Venezuelan Andes. * Represents genera recorded from SARF vegetation.

\begin{tabular}{|c|c|}
\hline Element & Genus \\
\hline \multirow{3}{*}{$\begin{array}{l}\text { Tropical (TRO) } \\
\text { Páramo endemics (P) } \\
\text { Andean alpine (NT-AA) } \\
\text { Neotropical montane (NT-M) }\end{array}$} & Libanothamnus Ernst, Paragynoxys* (Cuatrec.) Cuatrec., Ruilopezia Cuatrec. \\
\hline & Lachemilla (Focke) Rydb. \\
\hline & $\begin{array}{l}\text { Ageratina Spach, Arcytophyllum Willd. ex Schult. \& Schult. f., Aulonemia Goudot, Baccharis* } \\
\text { (Less.) DC., Bejaria Mutis ex L., Bomarea Mirb., Brachionidium* Lindl., Campyloneurum C. } \\
\text { Presl., Cavendishia Lindl., Centropogon C. Presl., Ceradenia L.E. Bishop, Cestrum* L., Chusquea } \\
\text { Kunth, Cochlidium* Kaulf., Corynaea* Hook. f., Cranichis* Sw., Cybianthus Mart., Dendroph- } \\
\text { tora Eichler, Deprea Raf., Diplostephium Kunth, Disterigma Sleumer, Elleanthus C. Presl., Epi- } \\
\text { dendrum L., Eriosorus* Fée, Excremis Willd., Freziera* Willd., Gaiadendron* G. Don, } \\
\text { Gamochaeta Wedd., Geissanthus* Hook. f., Glossoloma* Hanst., Gomphichis* Lindl., Greigia } \\
\text { Regel, Guzmania Ruiz \& Pavón, Hesperomeles Lindl., Huperzia Bernh., Isidrogalvia Ruiz \& } \\
\text { Pavón, Jamesonia Hook. \& Grev., Lellingeria* A.R. Sm. \& R.C. Moran, Macrocarpea* (Griseb.) } \\
\text { Gilg, Manettia Mutis ex L., Miconia Ruiz \& Pavón, Monnina Ruiz \& Pavón, Monochaetum (DC.) } \\
\text { Naud., Munnozia Ruiz \& Pavón, Myrcianthes* O. Berg, Odontoglossum Kunth, Oreopanax* } \\
\text { Decne. \& Planch., Pachyphyllum* Kunth, Paepalanthus Kunth, Palicourea Aubl., Pentacalia } \\
\text { Cass., Phoradendron* Nutt., Pleurothallis* R. Br., Psammisia* Klotzsch, Pterichis Lindl., Puya } \\
\text { Molina, Siphocampylus Pohl, Sphyrospermum Poepp. \& Endl., Terpsichore* A.R. Sm., Themis- } \\
\text { toclesia Klotzsch, Thibaudia* Ruiz \& Pavón, Tillandsia L., Tropaeolum L., Ugni Turcz. }\end{array}$ \\
\hline Wide tropical (WTR) & $\begin{array}{l}\text { Achyrocline (Less.) DC., Begonia* L., Chaetolepis (DC.) Miq., Clethra* L., Culcita* C. Presl., Cya- } \\
\text { thea* Sm., Elaphoglossum Schott ex J. Sm., Grammitis Sw., Hedyosmum* Sw., Histiopteris } \\
\text { (J. Agardh) J. Sm., Hymenophyllum Sm., Ilex L., Melpomene A.R. Sm. \& R.C. Moran, Mikania* } \\
\text { Willd., Myrsine L., Paesia J. St.-Hil., Peperomia* Ruiz \& Pavón, Phytolacca L., Pilea* Lindl., Pla- } \\
\text { giogyria* (Kunze) Mett., Psychotria* L., Sticherus C. Presl., Symplocos* Jacq., Xyris L., }\end{array}$ \\
\hline $\begin{array}{l}\text { Temperate } \\
\text { Austral-Antarctic (AA) }\end{array}$ & $\begin{array}{l}\text { Calceolaria L., Cortaderia Stapf., Cotula L., Drimys* J.R. Forst. \& G. Forst., Fuchsia* L., Gaul- } \\
\text { theria L., Hypoxis L., Muehlenbeckia Meisn., Nertera Banks ex Gaertn., Oreobolus R. Br., Or- } \\
\text { tachne Nees ex Steud, Orthrosanthus Sweet, Pernettya Gaudich., Sisyrhynchium L., Wein- } \\
\text { mannia* L. }\end{array}$ \\
\hline \multirow{2}{*}{$\begin{array}{l}\text { Holarctic }(\mathrm{HO}) \\
\text { Wide temperate (WTE) }\end{array}$} & $\begin{array}{l}\text { Castilleja Mutis ex L. f., Diplazium* Sw., Gentianella Moench, Halenia Borkh, Sibthorpia* L., } \\
\text { Vaccinium L. }\end{array}$ \\
\hline & $\begin{array}{l}\text { Agrostis L., Arenaria L., Calamagrostis Adans., Carex L., Danthonia DC., Daucus L., Epilo- } \\
\text { bium L., Festuca L., Galium L., Geranium L., Hieracium L., Hypericum L., Isoëtes L., Juncus L., } \\
\text { Luzula DC., Plantago L., Poa L., Polypogon Desf., Stellaria* L., Valeriana L., Viola L. }\end{array}$ \\
\hline Cosmopolitan (CO) & $\begin{array}{l}\text { Asplenium* L., Blechnum L., Cynoglossum L., Eleocharis R. Br., Equisetum L., Gnaphalium L., } \\
\text { Hydrocotyle L., Lycopodiella Holub., Lycopodium L., Ophioglossum L., Oxalis L., Polypodium } \\
\text { L., Rhynchospora Vahl, Rubus L., Solanum L., Thelypteris Schmidel, Utricularia L. }\end{array}$ \\
\hline
\end{tabular}


including Mediterranean climate distribution. Only six genera with Holarctic distribution (4\%) were found in the study area. The genus Sibthorpia, which corresponds to a small herb species and the fern
Diplazium have been found in borders of SARF vegetation or in the upper forest line. Excluding the SARF genera, the Holarctic element is represented by four genera (three of them herbaceous) or $3.7 \%$. Gen-

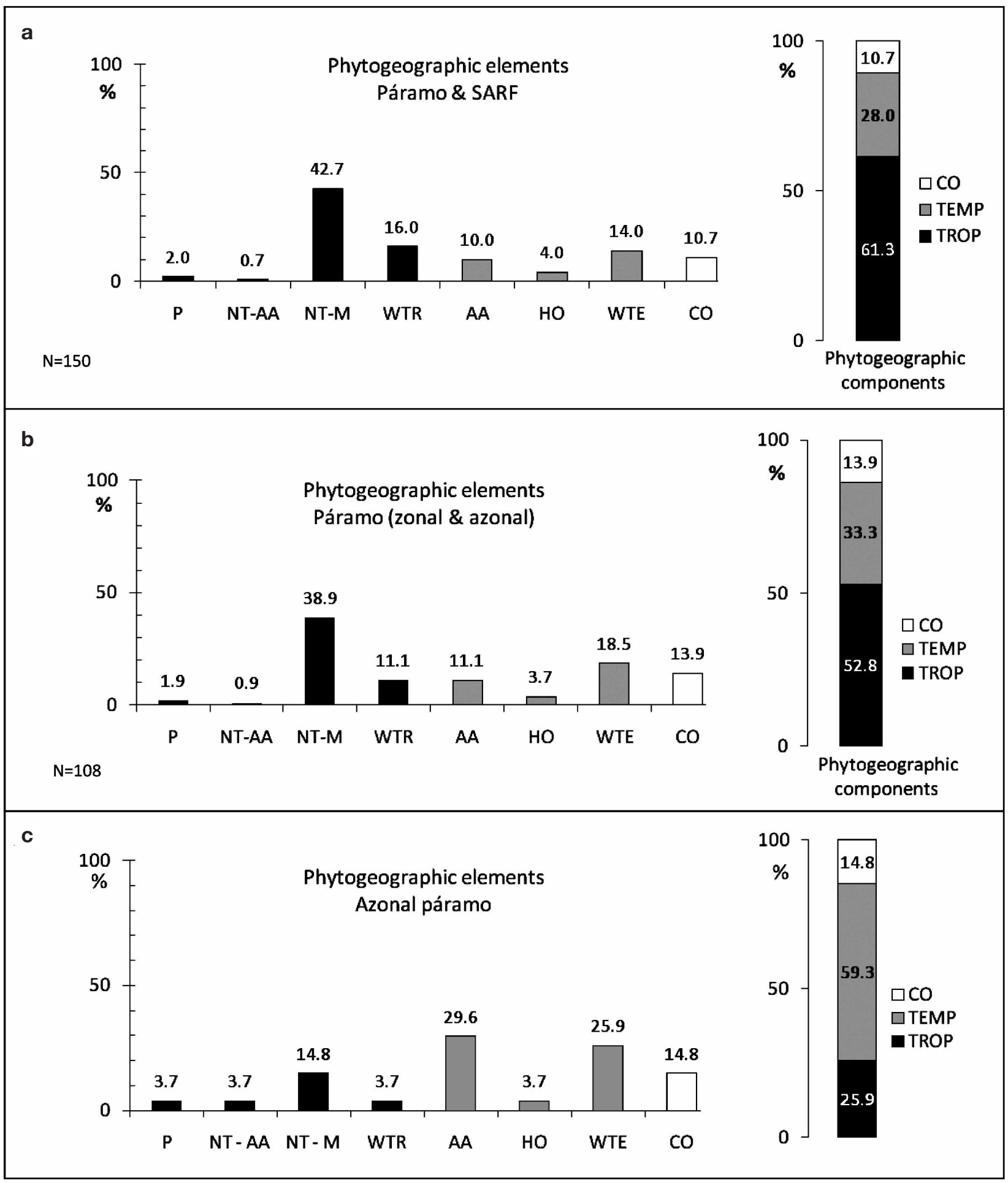

Fig. 2. Proportions (\%) of phytogeographic components and elements of (a) genera of páramo and SARF, (b) of all páramo genera, and (c) the genera from azonal communities from Ramal de Guaramacal, Andes, Venezuela. 
tianella was the only Holarctic genus counted from azonal páramo.

\section{Cosmopolitan component}

Cosmopolitan element genera are those with worldwide, or nearly so, distribution. The Cosmopolitan element is represented in the study area by sixteen genera $(10.7 \%)$. The fern genus Asplenium, represented by the species $A$. serra, is found in the understory of SARF vegetation. The Cosmopolitan component for only fifteen páramo genera (13 of them herbaceous) is represented by $13.9 \%$. In the azonal páramo the Cosmopolitan component is represented by four genera.

\section{Species geographical range}

The geographical range of the vascular species present in páramo areas of Ramal de Guaramacal, grouped in ten major groups (or distribution types), is shown in Table 4. Neotropical widespread distributed species all over in the whole Neotropics or in a wide range from Central America to Bolivia are broken down into five (1-5) groups. Andean distributed species are split into groups 6 to 9. Venezuelan endemic species (group 10) is divided into four subgroups. The number of vascular species, by taxonomic groups (ferns and Angiosperms) and percentages of the total are presented for each distribution category. From the total 229 taxa determined to species, only 156 species belong to proper páramo/subpáramo vegetation.

\section{Páramo flora relationship}

Fig. 3 shows the dendrograms of generic similarity among páramo sites resulting from the cluster analyses. In both graphs, over fifty percent of similarity, four main groups can be recognized. The closest relationships (about 90\%) among páramos is observed between the generic páramo floras of the Colombian Cordillera Oriental of each Sumapaz and Sierra Nevada del Cocuy, which are both closely related to Sierra Nevada de Mérida in Venezuela. The generic páramo flora of Ramal de Guaramacal shows the closest relationship to southern Ecuador páramo flora of Podocarpus National Park, with more than 50\% similarity, when considering Guaramacal generic flora from

Table 4. Analysis of the geographic range of the páramo flora based on 229 taxa with a defined geographical range in Appendix 1. F, ferns and fern allies; A, angiosperms; \%, percentage of total vascular species. Numbers in parentheses are percentages of total Venezuelan endemics.

\begin{tabular}{|c|c|c|c|c|c|c|c|c|c|}
\hline \multirow{2}{*}{$\begin{array}{l}\text { 음 } \\
\text { ㅇํㄴ }\end{array}$} & \multirow[t]{2}{*}{ Description } & \multicolumn{4}{|c|}{$\begin{array}{c}\text { Number } \\
\text { of páramo species }\end{array}$} & \multicolumn{4}{|c|}{$\begin{array}{c}\text { Number of páramo \& SARF } \\
\text { species combined }\end{array}$} \\
\hline & & $\mathbf{F}$ & A & Total & $\%$ & $\mathbf{F}$ & A & Total & $\%$ \\
\hline 1. & $\begin{array}{l}\text { Widespread in the Neotropics } \\
\text { and also occurring elsewhere }\end{array}$ & 4 & 10 & 14 & 9.0 & 5 & 10 & 15 & 6.6 \\
\hline 2. & Widespread in the Neotropics & 4 & 10 & 14 & 9.0 & 9 & 13 & 22 & 9.6 \\
\hline 3. & Widespread in Tropical South America & 0 & 3 & 3 & 1.9 & 0 & 3 & 3 & 1.3 \\
\hline 4. & $\begin{array}{l}\text { Widespread in Central America, } \\
\text { northern (western) South America } \\
\text { and the West Indies }\end{array}$ & 11 & 3 & 14 & 9.0 & 12 & 4 & 16 & 7.0 \\
\hline 5. & $\begin{array}{l}\text { Central America, northern and western } \\
\text { South America, including } \\
\text { the Guyana highlands }\end{array}$ & 2 & 3 & 5 & 3.2 & 3 & 5 & 8 & 3.5 \\
\hline 6. & Widespread from Costa Rica to Bolivia & 5 & 24 & 29 & 18.5 & 15 & 31 & 46 & 20.1 \\
\hline 7. & Widespread in the Andes from Col. to Bolivia & 5 & 16 & 21 & 13.5 & 13 & 25 & 38 & 16.6 \\
\hline 8. & $\begin{array}{l}\text { Confined to Venezuela, Colombia } \\
\text { and Ecuador }\end{array}$ & 1 & 9 & 10 & 6.4 & 1 & 12 & 13 & 5.7 \\
\hline 9. & Confined to Venezuela and Colombia & 3 & 13 & 16 & 10.3 & 3 & 19 & 22 & 9.6 \\
\hline \multirow[t]{5}{*}{10.} & Endemic to Venezuela: & & & & & & & & \\
\hline & 10.1. Andean region and Coastal cordillera & 0 & 2 & 2 & $1.3(6.7)$ & 0 & 4 & 4 & $1.7(8.7)$ \\
\hline & $\begin{array}{l}\text { 10.2. Andean region and Venezuelan } \\
\text { Guayana (highlands) }\end{array}$ & 1 & 2 & 3 & $1.9(10)$ & 3 & 2 & 5 & $2.2(10.9)$ \\
\hline & 10.3. Endemic to Andean region of Venezuela & 0 & 15 & 15 & $9.6(50)$ & 0 & 25 & 25 & $10.9(54.3)$ \\
\hline & 10.4. Endemic to Guaramacal & 0 & 10 & 10 & $6.4(33.3)$ & 0 & 12 & 12 & $5.2(26.1)$ \\
\hline \multicolumn{2}{|r|}{ Total Venezuelan endemics } & 1 & 29 & 30 & $19.2(100)$ & 3 & 43 & 46 & 20.1(100) \\
\hline \multicolumn{2}{|r|}{ Species Totals } & 36 & 120 & 156 & 100 & 64 & 165 & 229 & 100.0 \\
\hline
\end{tabular}


páramo and SARF combined (Fig. 3a), however no relationship of Guaramacal to any other páramo flora is observed when taking into account only the open generic páramo flora of Guaramacal.

Fig. 4 shows the resulting DCA ( $a, c)$ and PCA (b, d) ordination diagrams for both $\mathrm{A}(\mathrm{a}, \mathrm{b})$ and $\mathrm{B}(\mathrm{c}, \mathrm{d})$ datasets of presence/absence of genera and 8 páramo floras analyzed. An altitudinal gradient may be represented on axis 1 of DCA (a) and axis 2 of PCA (d), while a humidity gradient is mainly captured by axis 2 of PCA (b).

The results of ordination also show that for dataset A (that includes the páramo and SARF genera from Guaramacal) páramos with greatest values of humidity and rainfall according to Table 1 are grouped in line to the lower right corner on both DCA(a) and PCA(b) diagrams (e.g. Tatamá massif, 4100 m, 2000-3000 $\mathrm{mm}$ /year (Cleef \& al., 2005); South Ecuador, PBR, 3695 m, 5000 mm/year (Lozano \& al., 2009); and Guaramacal, 3100 m, > 3200 mm/year and relative humidity of $100 \%$ during most part of the year), while drier and higher elevation páramos are grouped to the lower left corner of DCA(a) and upper left corner of PCA(b). However, that humidity relationship is not obvious for dataset B (that with Guaramacal only open páramo genera), where páramo sites seem to be arranged mainly in relation to an altitudinal gradient in axis 2 of $\mathrm{PCA}(\mathrm{d})$.

Compared to other generic páramo floras (Table 5), Guaramacal shows the greatest proportion of Neotropical montane element genera and the lowest proportion of Andean-Alpine element genera. The proportion of the Holarctic element is the lowest of all páramo floras compared, but the Cosmopolitan element is the highest.

Páramos of Colombian Cordillera Oriental (S.N. Cocuy and Sumapaz) and Sierra Nevada de Mérida show the most similar proportions of phytogeographic elements among them. Páramos of Costa Rica/Panama

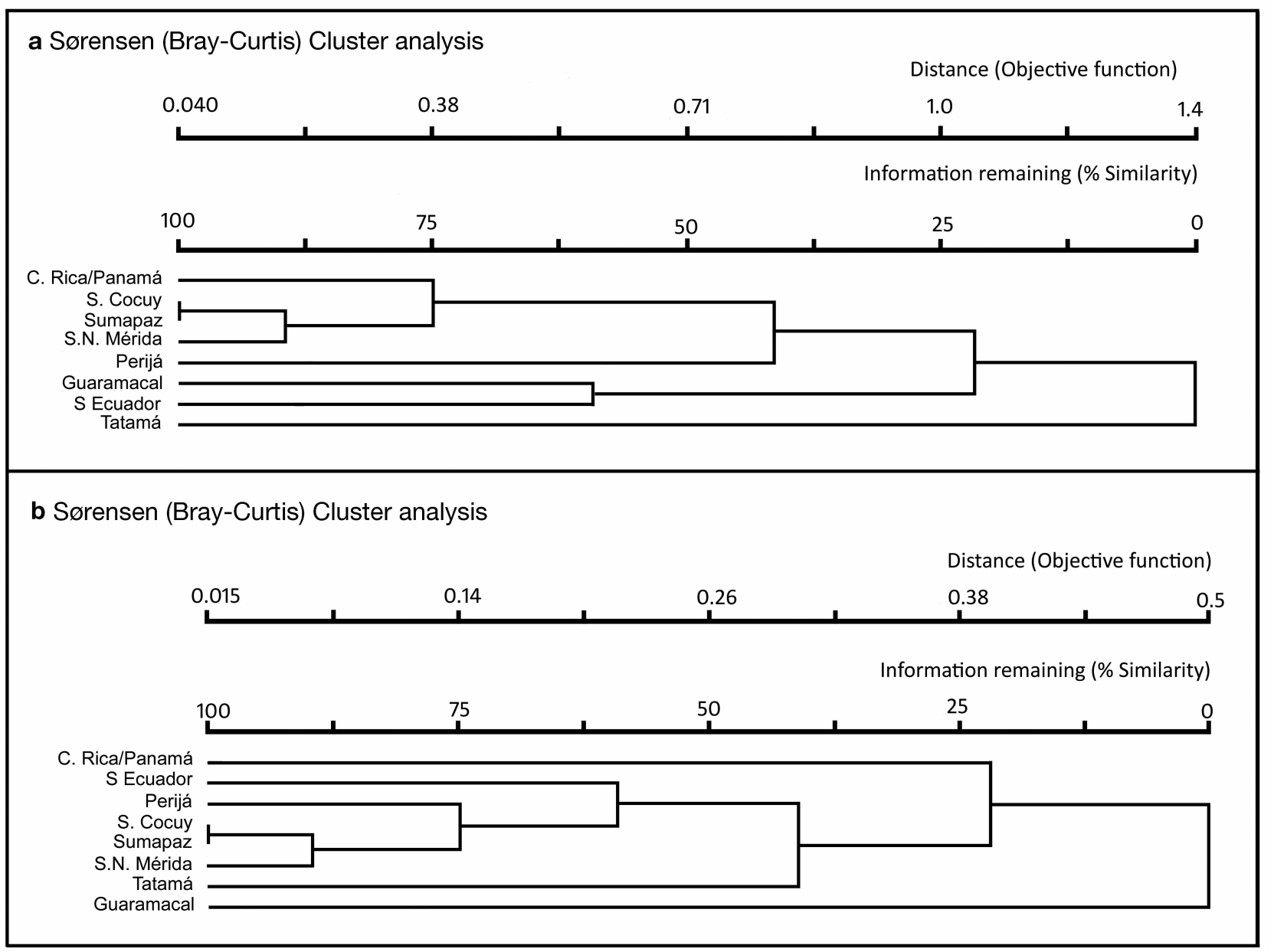

Fig. 3. Sørensen (Bray-Curtis) cluster analysis dendrogram of floristic similarity among 8 páramo sites based on (a) the presence/absence of 404 genera (including páramo \& SARF genera from Guaramacal), (b) the presence/absence of only 347 genera (including only proper páramo genera from Guaramacal). 
and Tatamá show the lowest proportion of Páramo endemic genera. Páramos of South Ecuador and Guaramacal show both more similar (the highest) proportions of Neotropical genera and also the lowest proportions of Holarctic genera.

\section{Discussion}

Floristic features

As in almost all páramo and other alpine floras (Rangel-Ch., 2000b; Vargas \& Sánchez, 2005; Rivera-
Díaz, 2007; Rangel-Ch. \& al., 2008; Briceño \& Morillo, 2002, 2006; Lozano \& al., 2009), Asteraceae and Poaceae rank as most dominant in terms of genera and species (Table 2). Remarkable for the páramo of the study area is the third position of Ericaceae with 10(8) genera and 15(13) species. Orchids and Grammitidaceae take the $4^{\text {th }}$ and $5^{\text {th }}$ position respectively in the general flora list, but for proper páramo flora only, Lycopodiaceae is more diverse. The relative importance of pteridophytes under wet climate is also sup-

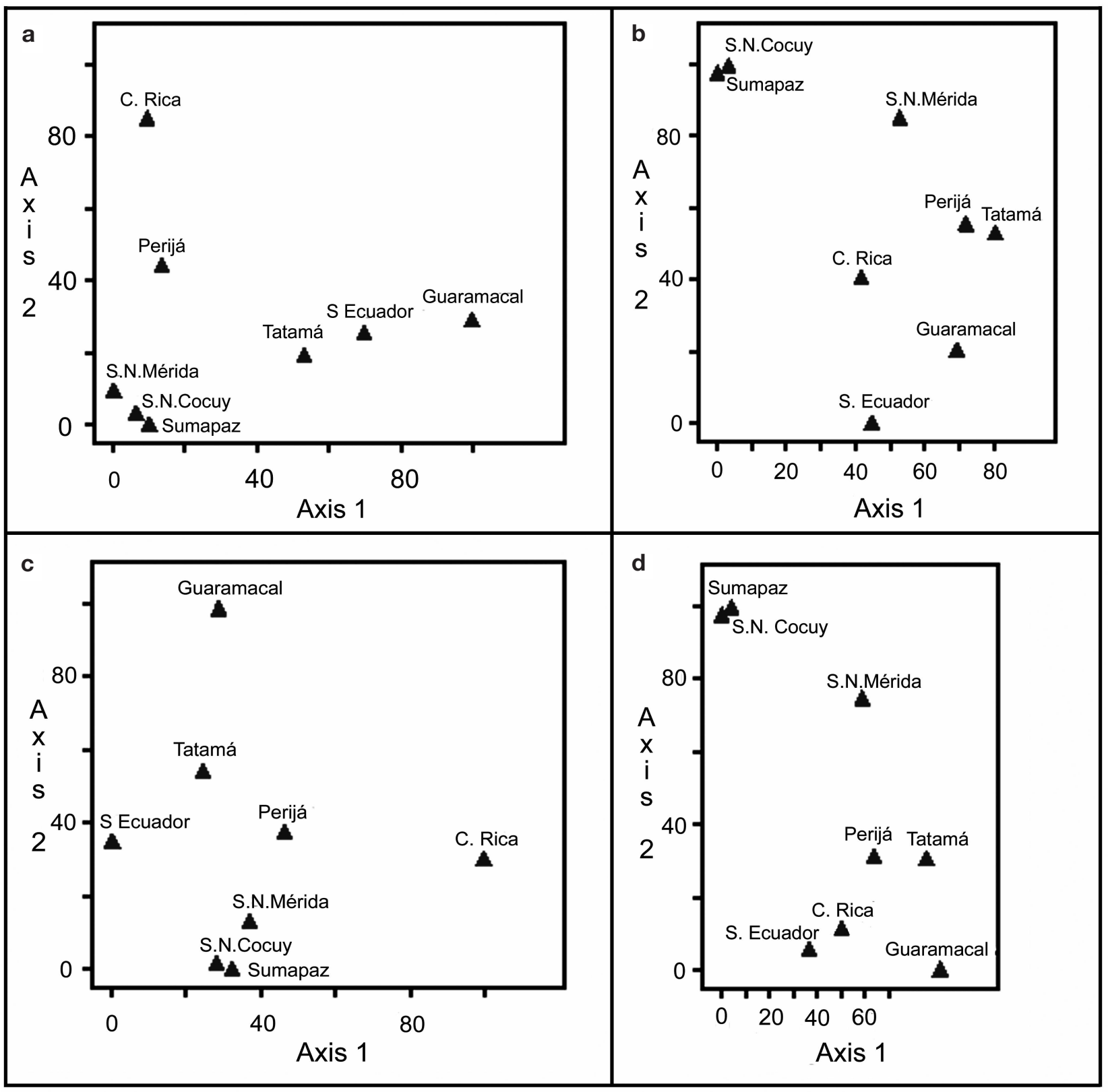

Fig. 4. DCA (a, c) and PCA (b, d) Ordination diagrams of 404 (a, b, including páramo \& SARF genera from Guaramacal) and 347 (c, d, including only proper páramo genera from Guaramacal) genera for 8 páramo floras datasets. a, DCA Axis 1 Eig $=0.422 ;$ Axis 2 $\mathrm{Eig}=0.321$; $\mathbf{b}$, PCA Axis $1 \mathrm{Eig}=473.827$; Axis $2 \mathrm{Eig}=121.424 ; \mathbf{c}$, DCA Axis $1 \mathrm{Eig}=0.223$; Axis 2 Eig = 0.189; $\mathbf{d}$, PCA Axis 1 Eig $=803.377 ;$ Axis 2 Eig $=87.539$ 
ported by Dryopteridaceae with Elaphoglossum displaying 11(5) species and Hymenophyllaceae with Hymenopbyllum containing 7(2) species.

In terms of number of species (Table 2) Elaphoglossum, Huperzia and Hymenophyllum and Chusquea take the first four positions in the general flora list. For páramo flora only, Chusquea, Huperzia and Rhynchospora with six species are the most diverse genera. The high diversity of Rbynchospora is remarkable. Rbynchospora sect. Paniculatae is supposed to be derived from lowland savanna stock (Wayt Thomas, pers. comm.). Earlier it was supposed that the ascent to the Andean páramos from savanna flora was most likely from the lower ranges of the eastern extreme/ end of the Andes of Venezuela (Cleef \& al., 1993). Rbynchospora oreoboloidea Gómez-Laur. of the Holarctic sect. Oreoboloides, a common species of the lower páramos in the northern Andes and in the Talamancas, is absent in the Guaramacal páramo. In Colombian páramos hardly there are found 6 different species of Rbynchospora in one study site.

Chusquea is considered here including three species formerly belonged to Neurolepis (Fisher \& al., 2009). One páramo species, Chusquea steyermarkii, has vicariant bamboo communities on the tepuies.

In conclusion, the taxa listed in Table 2 are almost all indicative of wet páramo climate. Hypericum and Pentacalia contain species thriving both under wet and drier páramo climate.

\section{Phytogeographical composition at genus level}

Based on the studies of the Tatamá páramo flora (Cleef, 2005) or that of the Talamancas in Costa Rica (Cleef \& Chaverri, 1992) we expected that humidity would play a role in determining the floristic composition of the Guaramacal range. In fact values for the Neotropical montane element $(38.9 \%)$ are high in the Guaramacal páramo, as well as for the Austral-
Antarctic element (11.1\%). Increased values for the Austral-Antarctic element also have been observed in the Podocarpus National Park, Tatamá and Talamanca páramos. However the substantial proportion of the Neotropical montane element may also be related to the low altitude of the Guaramacal range, $3000 \mathrm{~m}$ more or less, and one summit at $3130 \mathrm{~m}$. Páramo endemic genera rank low $(2 \%)$, probably also because of the general low altitude and one predominant humid climate type. There are also fewer distinct habitats in the Guaramacal páramo, as caused by the limited altitudinal amplitude of maximally about $200 \mathrm{~m}$, but most of the range even less. It is striking that the Andean-alpine element is represented only by one genus (Lachemilla) and that the Holarctic element only accounts for $3.6 \%$. Genera belonging to both these elements are mostly herbaceous and favoured by higher altitude. Further they are well adapted to periodical stress by dryness (Gutte, 1992). We suppose that bamboo páramo has been present in the summit area of Ramal de Guaramacal since Holocene times and that the prevailing wet climate served as a kind of filter preventing the arrival or survival of dry páramo species from the Mérida páramos.

Another interesting feature is the relative isolation of the Guaramacal páramo from the main cordillera of the Sierra Nevada de Mérida. A small connection is found on the northern side at about $2200 \mathrm{~m}$. During glacial times the summit areas of Guaramacal range were glaciated; remnants of former glacial lakes with terminal moraines are still present at different sites in the páramo belt as well as at lower altitude of about 2000 m near the Park headquarters. Páramo vegetation actually occurred during glacial times at lower altitude along the very steep slopes. In the uppermost part of Guaramacal range with a type of superpáramo, which is completely absent today. Isoëtes karstenii, a submerged species found from grass páramo up to the

Table 5. Proportions (\%) of phytogeographic elements of páramo genera for seven additional páramo floras compared to Guaramacal. (a) SARF and páramo genera combined, (b) páramo genera only.

\begin{tabular}{|c|c|c|c|c|c|c|c|c|c|}
\hline \multirow{2}{*}{$\begin{array}{l}\text { Phytogeographic } \\
\text { element }\end{array}$} & \multicolumn{2}{|c|}{ Guaramacal } & \multirow{2}{*}{$\begin{array}{c}\text { South } \\
\text { Ecuador }\end{array}$} & \multirow{2}{*}{ Perijá } & \multirow{2}{*}{$\begin{array}{l}\text { S. N. } \\
\text { Cocuy }\end{array}$} & \multirow{2}{*}{$\begin{array}{l}\text { S. N. } \\
\text { Mérida }\end{array}$} & \multirow{2}{*}{ Sumapaz } & \multirow{2}{*}{ Tatamá } & \multirow{2}{*}{$\begin{array}{c}\text { Costa } \\
\text { Rica }\end{array}$} \\
\hline & (a) & (b) & & & & & & & \\
\hline$P$ & 2.0 & 1.9 & 4 & 5.8 & 6.5 & 5.4 & 4.8 & 1.8 & 1.7 \\
\hline NT-AA & 0.7 & 0.9 & 5.5 & 3.6 & 8.4 & 8.1 & 7.1 & 8.0 & 3.4 \\
\hline NT-M & 42.7 & 38.9 & 32.5 & 27.0 & 27.6 & 22.3 & 25.7 & 25.7 & 27.7 \\
\hline WTR & 16 & 11.1 & 12 & 12.4 & 7.9 & 8.1 & 8.6 & 9.7 & 8.5 \\
\hline$A A$ & 10 & 11.1 & 13 & 10.2 & 10.7 & 10.8 & 12.4 & 14.2 & 12.4 \\
\hline $\mathrm{HO}$ & 4.0 & 3.7 & 10.5 & 13.9 & 12.1 & 14.2 & 11.9 & 8.8 & 16.4 \\
\hline WTE & 14.0 & 18.5 & 13.5 & 20.4 & 18.2 & 23.0 & 18.6 & 22.1 & 19.2 \\
\hline $\mathrm{CO}$ & 10.7 & 13.9 & 9 & 6.6 & 8.4 & 8.1 & 11.0 & 9.7 & 10.7 \\
\hline Total \% & 100 & 100 & 100 & 100 & 100 & 100 & 100 & 100 & 100 \\
\hline Total genera & 150 & 108 & 200 & 137 & 214 & 148 & 210 & 113 & 177 \\
\hline
\end{tabular}


highest lakes in the superpáramo in Colombia (Cleef, 1981; Salamanca \& al., 2003) and Venezuela (FuchsEckert, 1982; Small \& Hickey, 2001) has been found in a small lake in the Guaramacal páramo. Its presence in a glacial lake in the modern páramo of Ramal de Guaramacal can probably be considered as a 'glacial relict'. The Temperate component is best represented in azonal páramo vegetation (Sphagnum bogs) on top of Ramal de Guaramacal (Fig. 2c).

When the genera of the SARF vegetation in the Guaramacal bamboo páramo are taken into account the overall proportion of the Tropical component rises from $53.6 \%$ to $61.6 \%$, mainly because of more Neotropical montane and Wide tropical genera. For comparison with other páramo floras (Table 5), the taxa from SARF vegetation (column a) have not to be considered, though, sometimes this is difficult to do as well. Looking at the case of the extremely humid páramos of Podocarpus National Park in southern Ecuador (Lozano \& al., 2009), with a gradual transition of SARF into shrub páramo, it is noticeable that even the trees adapt to the general structure of shrub páramo vegetation (Bussmann, 2002; Richter \& Moreira-Muñoz, 2005; Peters, 2009, Lozano \& al., 2009; Cleef, pers. obs.).

\section{Species geographic range}

The tropical American part of the vascular flora of Páramo de Guaramacal is largely composed of (1) Neotropical widespread distributed species all over the Neotropics or in a wide range from Central America to Bolivia, (2) a group of Andean distributed species, part of them confined to the northern Andes and part widespread in the Andes from Colombia to Bolivia, and (3) a group of Venezuelan endemics (Table 4).

There is quite a difference between the 156 species with defined geographical distribution range reported for the Guaramacal páramo and the 229 species for the páramo including the SARF islands of Guaramacal. However, the phytogeographical proportions change slightly between both data bases: they maintain rather the same percentages. Looking more closely at the three main distribution types of the Guaramacal páramo flora (sensu stricto, without the SARF islands) we can state that there are 50 species, i.e. ca. $32 \%$, for the groups or distribution types 1-5 (e 4), these species displaying a more wide Neotropical distribution. The second and largest species group includes the distribution types 6-9 and is basically tropical Andean in distribution and accounts for seventy six species or about $49 \%$. Group 10 contains thirty species (about 19\%) all endemic to Venezuela.
Ten species $(6.4 \%)$ are narrow endemics of the Guaramacal páramo. They include 3 species of Espeletiinae stem rosettes: two species of Ruilopezia, and one species of Libanothamnus. Also, two species of Miconia, one species each of Bomarea, Epidendrum, Festuca, Ilex and Rhynchospora.

About 70 species or about $30 \%$ of the Guaramacal páramo species are shared with Central America - surprising given the distance and remoteness of Ramal de Guaramacal, although 30 of them correspond to ferns (Table 4$)$. In contrast, only 3 species $(1.9 \%)$ are shared with the Guayana Highlands which are at much closer distance indicating lack of exchange between these two areas. Most remarkable is the northernmost extension of the bamboo species Chusquea steyermarkii.

\section{Páramo flora relations}

We found a strong floristic similarity and similar phytogeographical composition among the páramo floras of Sierra Nevada del Cocuy, Sumapáz and Mérida páramos (Figs. 3, 4; Table 5). These mountain chains are contiguous in geographical position and display similar climatic characteristics with regard to the exposition of the ascending trade winds loaded with atmospheric water and the drier wind shadow areas. The Central American páramos of Panamá and Costa Rica, which are more humid, present about $75 \%$ similarity of páramo flora with those of the Mérida and Colombian Eastern Cordillera páramos (Fig. 3a). The Colombian Perijá páramo (drier side) ranks with about $40 \%$ similarity versus the wet páramo cluster of Guaramacal and PNP in S. Ecuador. Both remote páramo floras are similar at about a $60 \%$ value, which is most remarkable, because of the large distance between both areas. The similarity between the páramo floras of Guaramacal and PNP of South Ecuador is observed only when considered the páramo and SARF genera of Guaramacal (Fig. 3a). When considered only open páramo genera of Guaramacal (Fig. 3b), the páramo flora of Guaramacal is not related to any other of the paramo floras analyzed, and in this case PNP (South Ecuador) flora appears to be rather related with the group formed by the páramo of Perija and the group of drier and higher paramos of S. Cocuy, Sumapáz and S.N. Mérida, conversely, in this case, the páramo flora of Costa Rica/Panama has little relationship with this group. On the other hand, in the DCA and PCA ordinations, when SARF genera of Guaramacal are not included (Fig. 4c, d), the relationship to a humidity gradient is not so obvious, and an altitudinal gradient seem to prevail in PCA (Fig. 4d), while in the DCA (Fig. 4c) the relationship to those 
environmental variables is not so clear, and instead of them a latitudinal gradient may be detected.

Judging from the results it is most clear that the wet páramos floras are more similar to each other than to seasonally dry páramos (containing both dry bunchgrass páramo and bamboo páramo). In the case of the exclusively wet páramos it appears that humidity is more important than a temperature gradient. In fact the Ecuadorian Podocarpus National Park and Guaramacal páramos are similar in that both are relatively low in altitude with a maximum of about $200 \mathrm{~m}$ altitudinal amplitude in Guaramacal and about 400-500 m in the Podocarpus National Park although the highest core area of the latter reaches $\sim 3700 \mathrm{~m}$ in elevation. That the ambient humidity gradient apparently overrules that of temperature (viz. altitude), seems also confirmed by the DCA en PCA ordination diagrams of Fig. $4(\mathrm{a}, \mathrm{b})$, which are based on a comparison of eight páramo floras.

\section{Acknowledgements}

Authors acknowledge Joost Duivenvoorden (Amsterdam), and Beryl Simpson (Austin) for their important comments of an earlier version of the manuscript. Beryl was also helpful in correcting and language editing. We thank Pablo Lozano (Quito) for allowing us to review his at that time unpublished data from southern Ecuador páramos for comparison.

\section{References}

Acosta-Solís, M. 1984. Los páramos andinos del Ecuador. Publicaciones científicas MAS, Quito.

Aymard, G. 1999. Aspectos sobre la fitogeografía de la flora de las montañas de Guaramacal en los Andes de Venezuela. In: Cuello, N. (ed.), Parque Nacional Guaramacal: 101-106. Unellez- Fundación Polar. Caracas.

Barrington, D.S. 2005. Helechos de los páramos de Costa Rica. In: Kappelle, M. \& Horn, S.P. (eds.), Páramos de Costa Rica: 375 395. INBio, Santo Domingo de Heredia.

Bono, G. 1996. Flora y vegetación del estado Táchira. Monografie XX. Museo Regionale di Scienze Naturali, Torino.

Briceño, B. \& Morillo, G. 2002. Catálogo abreviado de las plantas con flores de los páramos de Venezuela. Parte I. Dicotiledóneas (Magnoliopsida). Acta Botánica Venezuelica 25(1): $1-46$.

Briceño, B. \& Morillo, G. 2006. Catálogo de las plantas con flores de los páramos de Venezuela. Parte II. Monocotiledóneas (Liliopsida). Acta Botánica Venezuelica 29(1): 89-134.

Bussmann, R.W. 2002. Estudios florísticos de la vegetación en la Reserva Biológica de San Francisco (ECSF) Zamora - Chinchipe. Herbario LOJA (Ecuador) 8: 1-106.

Chacón, J., Madriñán, S., Chase, M.W. \& Bruhl, J.J. 2006. Molecular phylogenetics of Oreobolus (Cyperaceae) and the origin and diversification of the American species. Taxon 55(2): 359-366.

Cleef, A.M. 1979. The phytogeographical position of the neotropical vascular páramo flora with special reference to the Colombian Cordillera Oriental. In: Larsen, K. \& al. (eds.), Tropical Botany:175-184. Academic Press, London.
Cleef, A.M. 1981. The vegetation of the páramos of the Colombian Cordillera Oriental. Dissertationes Botanicæ 61, Cramer, Vaduz.

Cleef, A.M. 2005. Phytogeography of the generic vascular páramo flora of Tatamá (Western Cordillera), Colombia. In: Van der Hammen, T. \& al. (eds.), La Cordillera Occidental colombiana Transecto de Tatamá. Studies on Tropical Andean Ecosystems 6: 661-668. Cramer/Borntraeger, Berlin-Stuttgart.

Cleef, A.M. \& Chaverri, A. 1992. Phytogeography of the páramo flora of Cordillera Talamanca, Costa Rica. In: Balslev, H. \& Luteyn, J. (eds.), Páramo: an Andean ecosystem under buman influence: 45-60. Academic Press, London.

Cleef, A.M., Van der Hammen, T. \& Hooghiemstra, H. 1993. The savanna relationship in the Andean páramo flora. Opera Botanica 121: 285-290. (O. Hedberg Festschrift).

Cleef, A.M., Rangel-Ch, J.O., Salamanca, S., Ariza-N, C. \& Van Reenen, G.B.A. 2005. La vegetación del páramo del Macizo de Tatamá, Cordillera Occidental, Colombia. In: Van der Hammen, T. \& al. (eds.), La Cordillera Occidental colombiana - Transecto de Tatamá. Estudios de Ecosistemas Tropandinos 6: 377 468. Cramer/Borntraeger, Berlin-Stuttgart.

Cuatrecasas, J. 1934. Observaciones geobotánicas en Colombia. Trabajos del Museo Nacional de Ciencias Naturales Madrid, Série Botánica 27: 1-144.

Cuatrecasas, J. 1958. Aspectos de la vegetación natural de Colombia. Revista de la Academia Colombiana de Ciencias Exactas, Fisicas y Naturales 10: 221-264.

Cuello, N. (ed.). 1999. Parque Nacional Guaramacal. Unellez Fundación Polar, Caracas.

Cuello, N. \& G. Aymard. 2008. Ilex guaramacalensis, a new species (Aquifoliaceae) from the Ramal de Guaramacal in the Venezuelan Andes. Novon 18: 319-324.

Cuello, N. \& Cleef, A.M. 2009a. The forests of Ramal de Guaramacal in the Venezuelan Andes. Phytocoenologia 39(1): 109-156.

Cuello, N. \& Cleef, A.M. 2009b. The páramo vegetation of Ramal de Guaramacal, Trujillo state, Venezuela. I. Zonal communities. Phytocoenologia 39(3): 295-329.

Cuello, N. \& Cleef, A.M. 2009c. The páramo vegetation of Ramal de Guaramacal, Trujillo state, Venezuela. II. Azonal vegetation. Phytocoenologia 39(4): 389-409.

Dorr, L., Stergios, B., Smith, A.R. \& Cuello, N. 2000. Catalogue of the vascular plants of Guaramacal National Park, Portuguesa and Trujillo States, Venezuela. Contributions from the United States National Herbarium 40: 1-155.

Faría S., N.B. 1978. Afinidades fitogeográficas de la flora vascular de los páramos venezolanos. Revista de la Facultad de Agronomía de la Universidad del Zulia, Maracaibo, Venezuela 4(2): 96-137.

Fisher, A.E., Triplett, J.K., Schiller H., Schroder, O., Kelchner, S. \& Clark, L.G. 2009. Paraphyly in the bamboo subtribe Chusqueinae (Poaceae: Bambusoideae) and a revised infrageneric classification for Chusquea. Systematic Botany 34(4): 673-683.

Franco-R., P. \& Betancur, J. 1999. La flora del Alto Sumapaz (Cordillera oriental, Colombia). Revista de la Academia Colombiana de Ciencias Exactas, Físicas y Naturales 23 (Suplemento especial): $53-78$.

Fuchs-Eckert, H.P. 1982. Zur heutigen Kenntnis von Vorkommen und Verbreitung der südamerikanishe Isoëtes-Arten. Proceedings of the Koninklijke Nederlandse Akademie van Wetenschappen C85: 205-260.

García E., E. \& Beck, S.G. 2006. Puna. In: Moraes, R.M. \& al. (eds.), Botánica Económica de los Andes Centrales: 51-76. Universidad Mayor de San Andrés, Plural Editores, La Paz.

Grubb, P.J. 1977. Control of forest growth and distribution on wet 
tropical mountains; with special reference to mineral nutrition. Annual Review of Ecology and Systematics 8: 83-107.

Gutte, P. 1992. Die Herkunft hochandiner zentralperuanischer Gattungen - Versuch einer Florenanalyse. Feddes Repertorium 103(3-4): 209-214.

Hagen, K.B., von \& Kadereit, J.W. 2003. The diversification of Halenia (Gentianiaceae): Ecological opportunity versus key innovation. Evolution 57(11): 2507-2518.

Hooghiemstra, H., Wijninga, V.M. \& Cleef, A.M. 2006. The paleobotanical record of Colombia: Implications for biogeography and biodiversity. Annals of the Missouri Botanical Garden 93: 297-325.

Jørgensen, P.M. \& Ulloa Ulloa, C. 1994. Seed plants of the high Andes of Ecuador: a checklist. - AAU Reports 34: 1-443. Aarhus University Press, Denmark.

Keating, P. L. 1999. Changes in páramo vegetation along an elevation gradient in southern Ecuador. Journal of the Torrey Botanical Society 126(2): 159-175.

Kelly, D.L., Tanner, E.V., Nic Lughadha, E.M. \& Kapos, V. 1994. Floristics and biogeography of a rain forest in the Venezuelan Andes. Journal of Biogeography 21: 421-440.

Lozano, P., Cleef, A.M. \& Bussmann, R. (2009): Phytogeography of the vascular páramo flora of Podocarpus Biosphere Reserve, South Ecuador. Arnaldoa 16(2): 69-85.

Luteyn, J. L. 1999. Páramos: a checklist of plant diversity, geographical distribution, and botanical literature. Memoirs of the New York Botanical Garden 84: 1-278.

Mabberley, D.J. 2008. Mabberley's plant-book. A portable dictionary of plants, their classification and uses. $3 \mathrm{rd}$ ed. Cambridge Univ. Press, New York.

McCune, B. \& Mefford, M.J. 1999. PC-ORD. Multivariate Analysis of Ecological Data. Version 4.10. MjM Software, Gleneden Beach, Oregon.

Meudt, H.M. \& Simpson, B.B. 2007. Phylogenetic analysis of morphological characters in Ourisia (Plantaginaceae): taxonomic and evolutionary implications. Annals of the Missouri Botanical Garden 94: 554-570.

Monasterio, M. 1980. Las formaciones vegetales de los páramos de Venezuela. In: Monasterio, M. (ed.), Estudios ecológicos en los páramos andinos: 93-158. Ediciones de la Universidad de los Andes, Mérida.

Monasterio, M. \& S. Reyes. 1980. Diversidad ambiental y variación de la vegetación en los páramos de los Andes Venezolanos. In: Monasterio, M. (ed.), Estudios ecológicos en los páramos andinos: 47-91. Ediciones de la Universidad de los Andes, Mérida.

Niño, M., Dorr, L. \& Stauffer, F.W. 2005. Una nueva especie de Aiphanes (Arecaceae) de la Cordillera de Mérida, Venezuela. Sida 21: 1529-1606.

Ortega, F., G. Aymard \& Stergios, B. 1987. Aproximación al conocimiento de la flora de las Montañas de Guaramacal, Edo. Trujillo, Venezuela. Biollania 5: 1-60.

Pedraza-Peñaloza, P., Betancur, J. \& Franco-Rosselli, P. 2004. Chisacá, un recorrido por los páramos andinos. Instituto de Ciencias Naturales e Instituto de Investigación de Recursos Biológicos Alexander von Humboildt, Bogotá.

Peters, T. 2009. Struktur und ökologische Merkmale der oberen Waldgrenze in der Andinen Depression. Ph.D. Thesis FriedrichAlexander University, Erlangen-Nürnberg.

Ramsay, P.M. 1992. The páramo vegetation of Ecuador: the community ecology, dynamics and productivity of tropical grasslands in the Andes. PhD thesis, University of Wales, UK. 274 pp.

Rangel-Ch., J.O. (ed.). 2000a. Colombia Diversidad Biótica III, La región paramuna de Colombia. Unibiblos, Universidad Nacional de Colombia, Bogotá.
Rangel-Ch., J.O. 2000b. Catálogo florístico de los macizos de Chingaza y Sumapaz. In: Rangel-Ch., J.O. (ed.), Colombia Diversidad Biótica III, La región paramuna de Colombia: 599- 657. Unibiblos, Universidad Nacional de Colombia, Bogotá.

Rangel-Ch, J.O. 2006. The biodiversity of the Colombian paramo region and its relation to antropogenic impact. In: Spehn, E., Lieberman, M. \& Korner, C. (eds), Land use change and mountain biodiversity: 103-118. CRC Press. Taylor \& Francis Group. Boca Raton, Florida.

Rangel-Ch., J.O., Rivera, O. \& Cleef, A.M. 2008. Flora vascular del macizo Sumapaz. In: Van der Hammen, T. \& al. (eds.), La Cordillera Oriental Colombiana - Transecto Sumapaz. Estudios de ecosistemas tropandinos 7: 203-210. J. Cramer, Berlin, Stuttgart.

Ricardi, M, Gaviria, J. \& Estrada, J. 1997. La Flora del Superpáramo venezolano y sus relaciones fitogeográficas a lo largo de Los Andes. Plantula 1(3): 171-187.

Ricardi, M, Gaviria, J. \& Estrada, J. 2000. Los Andes de Mérida, una nueva subprovincia fitogeográfica de la provincia de los Andes del Norte. Plantula 3(1): 41-46.

Richter, M. \& Moreira-Muñoz, A. 2005. Heterogeneidad climática y diversidad vegetacional en el Sur de Ecuador: un método de fotoindicación. In: Weigend, M. \& al. (eds.), Bosques relictos del NO del Perú y SO de Ecuador. Revista Peruana de Biología 12: $217-238$

Rivera-Díaz, O. 2007. Caracterización florística de la alta montaña de Perijá. In: Rangel-Ch., J.O. (ed.), Colombia Diversidad biótica V: La alta montaña de la Serranía de Perijá: 71-132. Arfo Editores e Impresores Ltda. Bogotá.

Rivero, R. \& Ortega, F. 1989. Notas fitogeográficas y adiciones a la Pteridoflora de las montañas de Guaramacal, estado Trujillo, Venezuela. BioLlania 6: 133-142.

Salamanca, S., Cleef, A.M. \& Rangel, J.O. 2003. The páramo vegetation of the volcanic Ruíz-Tolima massif. In: Van der Hammen, T. \& Dos Santos, A.G. (eds.), La Cordillera Central Colombiana. Transecto Parque Los Nevados. Studies on Tropical Andean Ecosystems 5: 1-77. J. Cramer. Berlin-Stuttgart.

Schneider, J.V. 2001. Diversity, structure and biogeography of a succesional and mature upper montane forest of the Venezuelan Andes. Ph.D. Thesis. Andere Verlag, Frankfurt am Main.

Simpson, B.B. \& Todzia, C.A. 1990. Patterns and processes in the development of the high Andean flora. American Journal of Botany 77: 1419-1432.

Sklenár, P. \& Balslev, H., 2007. Geographic flora elements in the Ecuadorian superpáramo. Flora 202(1): 50-61.

Small, R.L. \& Hickey, R.J. 2001. Systematics of the northern Andean Isoëtes karstenii complex. American Fern Journal 91(2): 41-69.

Smith, J.M.B. \& Cleef, A.M., 1988. Composition and origins of the world's tropicalpine floras. Journal of Biogeography 15: 631645.

Stančík, D. 2004. Festuca dinirica and F. guaramacalana (Poaceae, Loliinae), two new species from the Venezuelan Andes. Novon 14(3): 341-344.

Stergios, B. \& Dorr, L. 2003. Bomarea amilcariana (Amarylidaceae). Acta Botánica Venezuelica 26: 31-40.

Taylor, C. 2002. Rubiacearum Americanarum Magna Hama Pars 10. New species and a new subspecies of Faramea (Coussareae) from Central and South America. Novon 12(4): 563-570.

Van der Hammen, T. \& Cleef, A.M. 1986. Development of the high Andean páramo flora and vegetation. In: Vuilleumier, F. \& Monasterio, M. (eds.), High altitude tropical biogeography: 153-201. Oxford University Press. Oxford.

Vareschi, V. 1970. Flora de los páramos de Venezuela. Universidad de los Andes, Ediciones del Rectorado, Mérida. 
Vargas, G. \& Sánchez, J.J. 2005. Plantas con flores de los páramos de Costa Rica y Panamá: El páramo ístmico. In: Kappelle, M. \& Horn, S.P. (eds.), Páramos de Costa Rica: 397-435. Editorial INBio, Santo Domingo de Heredia.

\section{Appendix 1}

\section{Species list range}

Species list from páramo areas [zonal (Pzo) and azonal (Paz) páramo vegetation, including, subpáramo (SP) and páramoconnected dwarf forest (SARF) vegetation islands] present in the summit of Ramal de Guaramacal in the Venzuelan Andes. Species distribution group (1-10.4) as presented in Table 3, Group 0 for unknown distribution. Introduced species indicated with asterisk (*).

\begin{tabular}{|c|c|c|}
\hline FAMILY/SPECIES & $\begin{array}{l}\text { Distr. } \\
\text { Group }\end{array}$ & VEG. \\
\hline ASPLENIACEAE & & \\
\hline $\begin{array}{l}\text { Asplenium serra Langsd. \& Fisch. } \\
\text { BLECHNACEAE }\end{array}$ & 2 & SARF \\
\hline Blechnum aff. atropurpureum A.R. Sm. & 10.2 & SP \\
\hline B. auratum (Fee) R.M. Tryon \& Stolze & 6 & SARF/Pzo \\
\hline B. binervatum (Poir) C.V. Morton & & $s_{1}$ \\
\hline $\begin{array}{l}\text { subsp. fragile (Desv). R.M. Tryon \& Stolze } \\
\text { B. schomburgkii (Klotzsch) C. Chr. }\end{array}$ & 2 & SARF \\
\hline CYATHEACEAE & 5 & PZO/SARГ \\
\hline Cyathea fulva (Mart. \& Gal.) Fee & 6 & SARF \\
\hline DENNSTAEDTIACEAE & & \\
\hline Histiopteris incisa (Thunb.) J. Sm. & 1 & Pzo \\
\hline Paesia acclivis (Kunze) Kuhn & 7 & Pzo/SARF \\
\hline DICKSONIACEAE & & \\
\hline Culcita coniifolia (Hook.) Maxon & 2 & SARF \\
\hline DRYOPTERIDACEAE & & \\
\hline Diplazium bians Kunze ex Klotzsch & 2 & SP/SARF \\
\hline Elaphoglossum andicola $(\mathrm{Fee}) \mathrm{T}$. Moore & 7 & SARF \\
\hline E. appressum Mickel & 7 & Pzo \\
\hline E. cf. lingua (C. Presl) Brack. & 4 & Pzo \\
\hline E. cuspidatum (Willd) Moore & 6 & SARF \\
\hline s Mickel & 7 & UMRF/SARF \\
\hline E. minutum (Pohl ex Fee) T. Moore & 4 & Pzo \\
\hline E. muscosum (Sw.) T. Moore & 4 & Pzo \\
\hline E. nigrocostatum Mickel & 7 & SARF \\
\hline E. paleaceum (Hook. \& Grev.) Sledge & 4 & Pzo \\
\hline E. papillosum (Baker) H. Christ. & 6 & SARF \\
\hline E. rbynchopbyllum H. Christ. & 10.2 & SARF/Pzo \\
\hline EQUISETACEAE & & \\
\hline Equisetum bogotense Kunth & 2 & Pzo \\
\hline GLEICHENIACEAE & & \\
\hline Sticherus revolutus (Kunth) Ching & 4 & Pzo \\
\hline GRAMMITIDACEAE & & \\
\hline Ceradenia intonsa L.E. Bishop, ined & 8 & $\mathrm{SP} / \mathrm{Pzo}$ \\
\hline Cochlidium pumilum L.E. Bishop & 7 & SARF \\
\hline Grammitis leptopoda (C.H. Wright) Copel. & 5 & Pzo \\
\hline $\begin{array}{l}\text { G.xanthotrichia (Kl.) A.R. Sm. } \\
\text { Lellingeria major (Copel.) A.R. S }\end{array}$ & 10.2 & SARF \\
\hline $\begin{array}{l}\text { Lellingeria major (Copel.) A.R. Sm. \& R.C. } \\
\text { Moran }\end{array}$ & 7 & SARF/Pzc \\
\hline L. myosuroides A.R. Sm. \& R.C. Moran & 1 & SARF/Pzo \\
\hline Melpomene flabelliformis (Lag. ex $\mathrm{S}_{\mathrm{w} .}$ ) & & \\
\hline A.R. Sm \& R.C. Moran & 1 & Pzo \\
\hline M. moniliformis (Lag. ex Sw.) A.R. Sm \& & & \\
\hline R.C. Moran & 4 & Pzo \\
\hline M. xiphopteroides (Liebm.) A.R. Sm. & 4 & Pzo \\
\hline M. sp. & 0 & Pzo \\
\hline Terpsichore cultrata (Bory ex Willd.) A.R. Sm. & 2 & SARF \\
\hline
\end{tabular}

\begin{tabular}{|c|c|c|}
\hline FAMILY/SPECIES & $\begin{array}{l}\text { Distr. } \\
\text { Group }\end{array}$ & VEG. \\
\hline T. longisetosa (Hook.) A.R. Sm. & 6 & SARF \\
\hline T. semibirsuta (Kl.) A.R. Sm. & 6 & SARF/SP \\
\hline \multicolumn{3}{|l|}{ HYMENOPHYLLACEAE } \\
\hline Hymenophyllum aff. apiculatum Mett. ex Kuhn & 5 & SARF \\
\hline H. fucoides (Sw.) Sw. & 2 & SARF \\
\hline H. karstenianum J.W. Sturm & 7 & SARF \\
\hline H. myriocarpum Hook. & 6 & SARF/Pzo \\
\hline H. sp. & 0 & Pzo \\
\hline H. tegularis (Desv.) Proctor \& Lourteig & 6 & SARF \\
\hline H. trichomanoides Bosch. & 2 & Pzo \\
\hline \multicolumn{3}{|l|}{ ISOETACEAE } \\
\hline Isoëtes karstenii $\mathrm{A}$. Braun & 9 & $\mathrm{Paz}$ \\
\hline \multicolumn{3}{|l|}{ LYCOPODIACEAE } \\
\hline Huperzia amentacea (B. Øllg.) Holub & 6 & Pzo \\
\hline H. cf. capellae (Herter) Holub. & 7 & Pzo \\
\hline H. eversa (Poir.) B. Øllg. & 6 & Pzo \\
\hline H. molongensis (Herter) Holub. & 7 & SARF/Pzo \\
\hline H. ocanana (Herter) Holub & 9 & Pzo \\
\hline H. riobambensis (Herter) B. Øllg. & 9 & Pzo \\
\hline H. rufescens Hook. Trevis & 7 & Pzo \\
\hline H. sp. & 0 & SARF \\
\hline Lycopodiella cernua (L.) Pic. Serm. & 1 & SP \\
\hline L. pendulina (Hook.) B. Øllg. & 6 & SP \\
\hline L. riofrioi (Sodiro) B. Øllg. & 6 & B-P \\
\hline Lycopodium clavatum subsp. contiguum $\mathrm{Kl}$. & 6 & $\mathrm{Paz} / \mathrm{Pzo}$ \\
\hline L. jussiaei Desv. ex Poir. & 4 & B-P \\
\hline L. thyoides H. \& B. ex Willd. & 2 & Pzo \\
\hline \multicolumn{3}{|l|}{ OPHIOGLOSSACEAE } \\
\hline Ophioglossum crotalophorioides Walter & 1 & $\mathrm{Paz} / \mathrm{Pzo}$ \\
\hline PLAGIOGYRIACEAE & & \\
\hline Plagiogyria pectinata (Liebm.) Lellinger & 4 & SARF/Pzo \\
\hline \multicolumn{3}{|l|}{ POLYPODIACEAE } \\
\hline $\begin{array}{l}\text { Campyloneurum amphostenon (Kunze } \\
\text { ex Klotzsch) Fée }\end{array}$ & 4 & Pzo \\
\hline Polypodium funckii Mett. & 7 & Pzo \\
\hline P. sp. & 0 & Pzo \\
\hline \multicolumn{3}{|l|}{ PTERIDACEAE } \\
\hline Eriosorus flexuosus (Kunth) Copel. & & \\
\hline var. flexuosus & 4 & SARF/Pzo \\
\hline Jamesonia imbricata (Sw.) Hook. \& Grev. & 7 & Pzo \\
\hline \multicolumn{3}{|l|}{ THELYPTERIDACEAE } \\
\hline Thelypteris cheilanthoides (Kunze) Proctor & 4 & Pzo \\
\hline T. frigida (H. Christ) A.R. Sm. & 6 & $\mathrm{Pzo} / \mathrm{SP}$ \\
\hline T. prolatipedis Lellinger & 6 & SARF \\
\hline \multicolumn{3}{|l|}{ APIACEAE } \\
\hline Daucus montanus H. \& B. ex Spreng. & 1 & Pzo \\
\hline Hydrocotyle venezuelensis Rose ex Mathias & 10.1 & Pzo/SARF \\
\hline \multicolumn{3}{|l|}{ AQUIFOLIACEAE } \\
\hline Ilex guaramacalensis Cuello \& Aymard & 10.4 & Pzo/SARF \\
\hline \multicolumn{3}{|l|}{ ARALIACEAE } \\
\hline Oreopanax discolor (Kunth) Decne. \& Planch. & 9 & SARF \\
\hline O. sp.1 & 0 & SARF \\
\hline O. sp.2 & 0 & SARF \\
\hline \multicolumn{3}{|l|}{ ASTERACEAE } \\
\hline Achyrocline moritzianum Klatt & 8 & Pzo \\
\hline A. vargasiana $\mathrm{DC}$. & 3 & SP \\
\hline Ageratina theifolia (Benth.) R.M. King & 9 & $\mathrm{Pzo} / \mathrm{SARF}$ \\
\hline Baccharis prunifolia Kunth & 7 & SP/SARF \\
\hline Cotula mexicana L. & 2 & $\mathrm{Paz}$ \\
\hline Diplostephium obtusum S.F. Blake & 10.3 & $\mathrm{Paz} / \mathrm{Pzo} / \mathrm{SA}$ \\
\hline
\end{tabular}




\begin{tabular}{|c|c|c|}
\hline FAMILY/SPECIES & $\begin{array}{l}\text { Distr. } \\
\text { Group }\end{array}$ & VEG. \\
\hline D. venezuelense Cuatrec. & 10.3 & Pzo \\
\hline Gamochaeta americana (Mill.) Wedd. & 1 & Pzo \\
\hline Hieracium avilae Kunth & 8 & $\mathrm{Paz} / \mathrm{Pzo}$ \\
\hline H. eriantbum Kunth & 7 & Pzo \\
\hline Libanothamnus griffinii (Ruiz-Terán & & \\
\hline \& Lóp. Fig.) Cuatrec. & 10.4 & Pzo/SARF \\
\hline Mikania nigropunctulata Hieron. & 5 & LMRF/SARF \\
\hline M. stuebelii Hieron. & 7 & SARF \\
\hline Munnozia senecionidis Benth. & 6 & Pzo \\
\hline $\begin{array}{l}\text { Paragynoxys cuatrecasasii Ruiz-Terán } \\
\text { \& López-Fig. }\end{array}$ & 10.3 & SARF \\
\hline Pentacalia cachacoensis (Cuatrec.) Cuatrec. & 9 & Pzo/SARF \\
\hline P. greenmaniana (Hieron.) Cuatrec. & 10.3 & Pzo/SARF \\
\hline P. theaefolia (Benth.) Cuatrec. & 7 & SARF \\
\hline P. vicelliptica (Cuatrec.) Cuatrec. & 10.3 & SARF \\
\hline Ruilopezia jabonensis (Cuatrec.) Cuatrec. & 10.3 & $\mathrm{Paz} / \mathrm{Pzo}$ \\
\hline $\begin{array}{l}\text { R. lopez-palacii (Ruiz-Terán } \\
\text { \& López-Figueiras) Cuatrec. }\end{array}$ & 10.4 & $\mathrm{Paz} / \mathrm{Pzo}$ \\
\hline R. paltonioides (Standl.) Cuatrec. & 10.3 & Pzo/SARF \\
\hline $\begin{array}{l}\text { R. viridis (Aristeguieta) Cuatrec. } \\
\text { Sonchus oleraceus L.* }\end{array}$ & 10.4 & Pzo \\
\hline BALANOPHORACEAE & & \\
\hline Corynaea crassa Hook.f & 6 & SARF \\
\hline BEGONIACEAE & & \\
\hline Begonia formosissima Sandwith & 10.3 & SARF-Pzo \\
\hline $\begin{array}{l}\text { B. lipolepis L.B. Sm. var. luteynorum } \\
\text { (L.B. Sm. \& Wassh.) Dorr }\end{array}$ & 10.3 & SP/SARF \\
\hline BORAGINACEAE & & \\
\hline $\begin{array}{l}\text { Cynoglossum amabile Stapf \& J.R. Drumm. } \\
\text { CAMPANULACEAE }\end{array}$ & 1 & Pzo \\
\hline Centropogon aff. elmanus E. Wimm. & 10.3 & SARF \\
\hline C. lanceolatus E. Wimm. & 10.3 & SP/Pzo \\
\hline Siphocampylus odontosepalus Vatke & 7 & $\mathrm{Pzo} / \mathrm{SP}$ \\
\hline CARYOPHYLLACEAE & & \\
\hline Arenaria venezuelana Briq. & 9 & $\mathrm{Paz} / \mathrm{Pzo}$ \\
\hline Stellaria cuspidata Willd. ex Schltdl. & 2 & SARF \\
\hline CHLORANTHACEAE & & \\
\hline Hedyosmum translucidum Cuatrec. & 7 & SARF \\
\hline Clethra fagifolia Kunth var. fagifolia & 6 & SARF/UMRF \\
\hline CLUSIACEAE & & \\
\hline Hypericum cardonae Cuatrec. & 6 & $\mathrm{Paz} / \mathrm{Pzo}$ \\
\hline H. juniperinum Kunth & 9 & $\mathrm{Paz} / \mathrm{Pzo}$ \\
\hline H. juniperinum $\times$ cardonae & 10.4 & $\mathrm{PAz}$ \\
\hline H. paramitanum N. Robson & 10.3 & Pzo/SARF \\
\hline CUNONIACEAE & & \\
\hline Weinmannia auriculata D. Don & 7 & SARF \\
\hline W. fagaroides Kunth & 2 & SARF \\
\hline W karsteniana Szyszyll. & 9 & SARF \\
\hline W. lechleriana Engl. & 7 & SARF \\
\hline ERICACEAE & & \\
\hline Bejaria aestuans L. & 6 & Pzo \\
\hline $\begin{array}{l}\text { Cavendishia bracteata (Ruiz \& Pavon } \\
\text { ex St.-Hil.) Hoerold }\end{array}$ & 6 & Pzo/SARF \\
\hline Disterigma acuminatum (Kunth) Nied. & 3 & Pzo \\
\hline D. alaternoides (Kunth) Nied. & 6 & Pzo/SARF \\
\hline Gaultheria anastomosans (L.f.) Kunth & 6 & Pzo/SARF \\
\hline G. buxifolia Willd. & 7 & Pzo \\
\hline G. erecta Vent. & 2 & Pzo/SARF \\
\hline G. glomerata (Cav.) Sleum. & 7 & Pzo \\
\hline G. hapalotricha A.C. Sm. & 7 & Pzo \\
\hline Pernettya prostrata (Cav.) DC. & 2 & $\mathrm{Pzo} / \mathrm{Paz}$ \\
\hline Psammisia bookeriana Klotzsch. & 9 & SARF \\
\hline
\end{tabular}

\begin{tabular}{|c|c|c|}
\hline FAMILY/SPECIES & $\begin{array}{l}\text { Distr. } \\
\text { Group } \\
\end{array}$ & VEG. \\
\hline Sphyrospermum buxifolium Poepp. \& Endl. & 5 & Pzo \\
\hline Themistoclesia dependens (Benth.) A.C. Smith & 8 & $\mathrm{Pzo} / \mathrm{SARF}$ \\
\hline Thibaudia floribunda Kunth. & 7 & SARF \\
\hline Vaccinium corymbodendron Dunal & 7 & Pzo/SARF \\
\hline \multicolumn{3}{|l|}{ GENTIANIACEAE } \\
\hline $\begin{array}{l}\text { Gentianella nevadensis (Gilg.) Weaver } \\
\text { \& Rüdenberg }\end{array}$ & 8 & $\mathrm{Paz} / \mathrm{Pzo}$ \\
\hline Halenia sp. & $\begin{array}{l}8 \\
0\end{array}$ & $\begin{array}{l}\text { Paz/Pzo } \\
\text { Pzo }\end{array}$ \\
\hline Macrocarpaea bracteata Ewan & 10.3 & UMRF/SARF \\
\hline \multicolumn{3}{|l|}{ GERANIACEAE } \\
\hline Geranium stoloniferum Standl. & 10.3 & $\mathrm{Paz} / \mathrm{Pzo}$ \\
\hline \multicolumn{3}{|l|}{ GESNERIACEAE } \\
\hline $\begin{array}{l}\text { Glossoloma chrysantbus (Pl. \& Tr.) J. Clark } \\
\text { LENTIBULARIACEAE }\end{array}$ & 10.3 & SARF \\
\hline $\begin{array}{l}\text { Utricularia alpina Jacq. } \\
\text { LORANTHACEAE }\end{array}$ & 2 & Pzo \\
\hline Dendrophtora sp. A. & 0 & Pzo/SARF \\
\hline Gaiadendron punctatum (R. \& P.) G. Don & 5 & UMRF/SARF \\
\hline Phoradendron sp. & 0 & Pzo/SARF \\
\hline \multicolumn{3}{|l|}{ MELASTOMATACEAE } \\
\hline Chaetolepis lindeniana (Naudin) Triana & 9 & $\mathrm{Pzo} / \mathrm{SARF}$ \\
\hline Miconia arbutifolia Naud. & 10.1 & SARF/SP \\
\hline M. elvirae Wurdack & 10.4 & SARF \\
\hline M. jahnii Pittier & 8 & SARF \\
\hline M. tinifolia Naud. & 8 & $\mathrm{Pzo} / \mathrm{SARF}$ \\
\hline Monochaetum discolor $\mathrm{H}$. Karst. & 10.3 & $\mathrm{Pzo} / \mathrm{SARF}$ \\
\hline \multicolumn{3}{|l|}{ MYRSINACEAE } \\
\hline Cybianthus laurifolius (Mez) Agost. & 9 & SARF \\
\hline C. marginatus (Benth.) Pipoly & 7 & Pzo/SARF \\
\hline C. stapfii (Mez) Ago & 9 & SARF \\
\hline bus andinu. & 8 & SARF \\
\hline Myrsine dependens & 6 & Pzo/SARF \\
\hline \multicolumn{3}{|l|}{ MYRTACEAE } \\
\hline Myrcianthes myrsinoides & 7 & SARF \\
\hline Ugni myricoides $(\mathrm{Ku}$ & 4 & Pzo \\
\hline \multicolumn{3}{|l|}{ ONAGRACEAE } \\
\hline Epilobium denticulatum Ruiz \& Pavon & 6 & Pzo \\
\hline Fuchsia membran & 10.3 & SARF \\
\hline \multicolumn{3}{|l|}{ OXALIDACEAE } \\
\hline Oxalis sp. & 0 & Pzo \\
\hline PHYTOLACCACEAE & & \\
\hline Phytolacca rugosa A. Brau & 6 & $\mathrm{Paz}$ \\
\hline \multicolumn{3}{|l|}{ PIPERACEAE } \\
\hline Peperomia acuminata Ruiz \& Pavon & 4 & SARF \\
\hline P. sp. 1 & 0 & SARF \\
\hline P. sp. 2 & 0 & SARF \\
\hline \multicolumn{3}{|l|}{ PLANTAGINACEAE } \\
\hline Plantago australis L. & 2 & Pzo \\
\hline \multicolumn{3}{|l|}{ POLYGALACEAE } \\
\hline Monnina meridensis Planch. \& Lind. ex Wedd & 10.3 & Pzo \\
\hline M. sp.1 & 0 & SARF \\
\hline M. sp.2 & 0 & SARF \\
\hline \multicolumn{3}{|l|}{ POLYGONACEAE } \\
\hline $\begin{array}{l}\text { Mueblenbeckia tamnifolia (Kunth) Meisn. } \\
\text { Rumex acetosella L.* }\end{array}$ & 2 & Pzo \\
\hline \multicolumn{3}{|l|}{ ROSACEAE } \\
\hline Hesperomeles obtusifolia (Pers.) Lindl. & 6 & $\mathrm{Paz} / \mathrm{Pzo} / \mathrm{SARF}$ \\
\hline H. sp. & 0 & Pzo/SARF \\
\hline Lachemilla verticillata (Fielding \& Gardner) & & \\
\hline Rothm. & 6 & $\mathrm{Paz}$ \\
\hline Rubus acanthopbyllos Focke & 7 & Pzo \\
\hline RUBIACEAE & & \\
\hline Arcytophyllum nitidum (Kunth) Schltdl. & 9 & Pzo \\
\hline
\end{tabular}




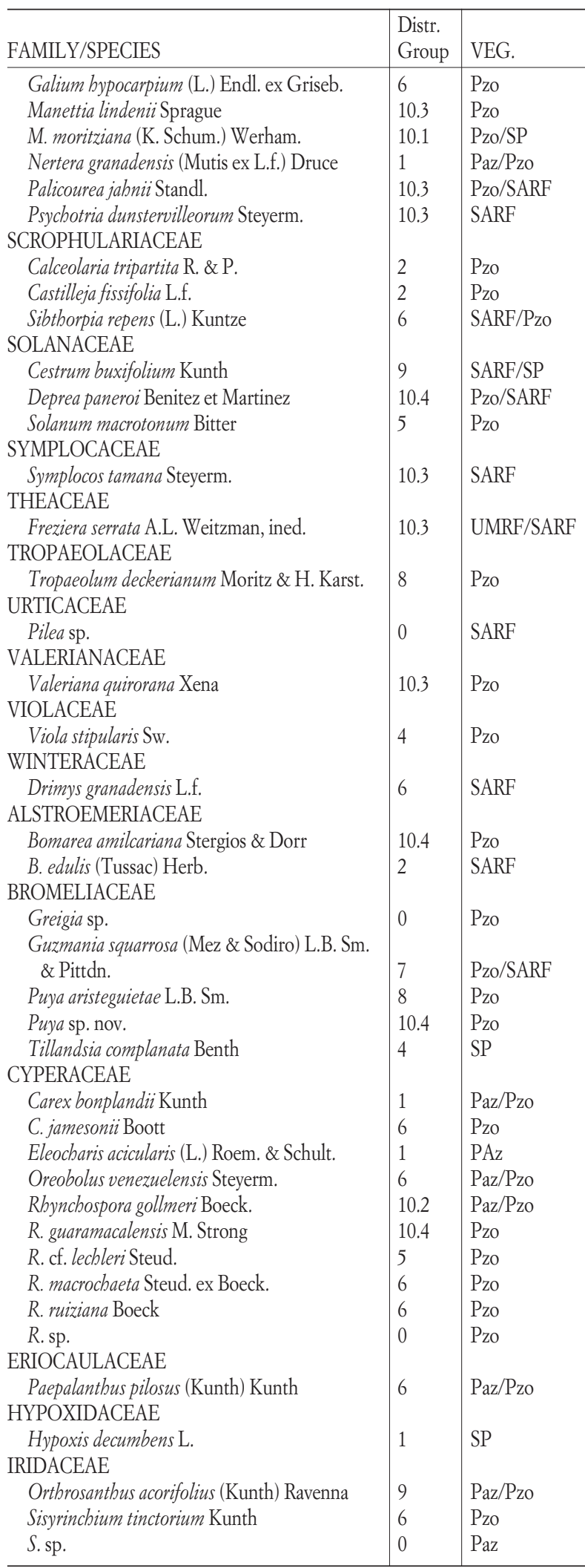

\begin{tabular}{|c|c|c|}
\hline FAMILY/SPECIES & $\begin{array}{l}\text { Distr. } \\
\text { Group }\end{array}$ & VEG. \\
\hline \multicolumn{3}{|l|}{ JUNCACEAE } \\
\hline Juncus bufonius L. & 1 & Pzo \\
\hline J. stipulatus Nees \& Meyen & 3 & Pzo \\
\hline Luzula gigantea Desv. & 6 & Pzo \\
\hline \multicolumn{3}{|l|}{ LILIACEAE } \\
\hline Excremis coarctata (Ruiz \& Pav.) Baker & 7 & Pzo \\
\hline \multicolumn{3}{|l|}{ ORCHIDACEAE } \\
\hline Brachionidium tuberculatum Lindl. & 7 & SARF \\
\hline Cranichis antioquensis Schltr. & 6 & SARF \\
\hline Elleanthus aurantiacus (Lindl.) Rchb.f & 2 & Pzo \\
\hline E. flavescens (Lindl.) Rchb.f. & 7 & Pzo \\
\hline E. maculatus (Lindl.) Rchb. f. & 6 & Pzo \\
\hline Epidendrum frutex Rchb.f. & 7 & Pzo \\
\hline E. guaramacalensis Hagsater & 10.4 & Pzo \\
\hline $\begin{array}{l}\text { Gomphichis costaricensis (Schltr.) Ames, } \\
\text { F.T. Hubb. \& Schweinf. }\end{array}$ & 6 & SP/SARF \\
\hline Odontoglossum megalopbium Lindl. & $\begin{array}{l}0 \\
7\end{array}$ & SARF \\
\hline O. ramosissimun Rchb.f. & 7 & Pzo \\
\hline O. schillerianum Rchb.f. & 9 & SARF \\
\hline Pachyphyllum crystallinum Lindl. & 6 & SARF \\
\hline Pleurothallis glossopogon Rchb. f. & 8 & SARF \\
\hline Pterichis multiflora (Lindl.) Schltr. & 8 & Pzo \\
\hline \multicolumn{3}{|l|}{ POACEAE } \\
\hline Agrostis basalis Luces & 10.1 & $\mathrm{PAz}$ \\
\hline A. perennans (Walter) Tucker & 1 & $\mathrm{PAz}$ \\
\hline A.sp. B & 0 & $\mathrm{PAz}$ \\
\hline \multicolumn{3}{|l|}{ Aulonemia ximenae L.G. Clark, Judz. \& } \\
\hline C.D. Tyrrell & 9 & SP \\
\hline Calamagrostis bogotensis (Pilg.) Pilg. & 6 & $\mathrm{Paz} / \mathrm{Pzo}$ \\
\hline C. planifolia (Kunth) Trin. ex Steud. & 7 & Pzo \\
\hline C.sp.A & 0 & $\mathrm{Paz} / \mathrm{Pzo}$ \\
\hline Chusquea aff. fendleri Munro & 9 & Pzo \\
\hline \multicolumn{3}{|l|}{ C. angustifolia (Soderstr. \& C.E. Calderón) } \\
\hline L.G. Clark & 9 & $\mathrm{Pzo} / \mathrm{Paz} / \mathrm{SAR}$ \\
\hline C. mollis (Swallen) L.G. Clark & 9 & $\mathrm{Pzo} / \mathrm{SP}$ \\
\hline C. spectabilis L.G. Clark & 8 & $\mathrm{Pzo} / \mathrm{SP}$ \\
\hline C. spencei Ernst. & 9 & Pzo/SARF \\
\hline C. steyermarkii L.G. Clark & 10.2 & Pzo \\
\hline C. tessellata Munro & 7 & Pzo \\
\hline Cortaderia hapalotricha (Pilg.) Conert. & 6 & $\mathrm{Paz} / \mathrm{Pzo}$ \\
\hline \\
\hline Festuca guaramacalana Stancik & 10.4 & Pzo \\
\hline Festuca sp. & 0 & Pzo \\
\hline Ortachne erectifolia (Swallen) Clayton & 6 & $\mathrm{PAz}$ \\
\hline Poa annua L.* & 1 & Pzo \\
\hline \multirow{2}{*}{\multicolumn{3}{|c|}{$\begin{array}{l}\text { Polypogon elongatus Kunth* } \\
\text { TOFIELDIACEAE }\end{array}$}} \\
\hline & & \\
\hline Isidrogalvia robustior (Steyerm.) Cruden. & 10.3 & Pzo \\
\hline XYRIDACEAE & & \\
\hline $\begin{array}{l}\text { Xyris subulata Ruiz \& Pav. } \\
\text { var. acutifolia Heimerl. }\end{array}$ & 6 & $\mathrm{Paz} / \mathrm{Pzo}$ \\
\hline
\end{tabular}

Associate Editor: J.L. Fernández Alonso Received: 10-III-2010 Accepted: 29-IX-2010 